Article

\title{
Impacts of Landscape Patterns on Ecosystem Services Value: A Multiscale Buffer Gradient Analysis Approach
}

\author{
Wanxu Chen ${ }^{1,2,3}$, Jie Zeng ${ }^{1,2, *}$, Yumei Chu ${ }^{4}$ and Jiale Liang ${ }^{5}$ \\ 1 Department of Geography, School of Geography and Information Engineering, China University \\ of Geosciences, Wuhan 430074, China; cugcwx@cug.edu.cn \\ 2 Research Center for Spatial Planning and Human-Environmental System Simulation, China University \\ of Geosciences, Wuhan 430074, China \\ 3 State Key Laboratory of Earth Surface Processes and Resource Ecology, Beijing Normal University, \\ Beijing 100875, China \\ 4 School of Foreign Languages, Xinyang University, Xinyang 464000, China; ym18903972543@163.com \\ 5 Department of Land Resource Management, School of Public Administration, China University \\ of Geosciences, Wuhan 430074, China; LJL0715@cug.edu.cn \\ * Correspondence: zengjie@cug.edu.cn
}

Citation: Chen, W.; Zeng, J.; Chu, Y.; Liang, J. Impacts of Landscape

Patterns on Ecosystem Services Value: A Multiscale Buffer Gradient Analysis Approach. Remote Sens. 2021, 13, 2551. https://doi.org/10.3390/rs13132551

Academic Editors: Mehebub Sahana, Hashem Dadashpoor, Priyank Patel and Alexander Follmann

Received: 6 June 2021

Accepted: 24 June 2021

Published: 29 June 2021

Publisher's Note: MDPI stays neutral with regard to jurisdictional claims in published maps and institutional affiliations.

Copyright: () 2021 by the authors. Licensee MDPI, Basel, Switzerland. This article is an open access article distributed under the terms and conditions of the Creative Commons Attribution (CC BY) license (https:// creativecommons.org/licenses/by/ $4.0 /)$.

\begin{abstract}
In recent decades, substantial changes have occurred in the spatial structure and form of landscapes in metropolises; these have greatly impacted ecosystem provision capacities. Clarifying the impact mechanism of landscape patterns on ecosystem services can provide insights into regional ecological conservation and sustainable development measures. Although previous studies have explored the impacts of landscape patterns on ecosystem services at multiple scales, few studies have been conducted using the buffer gradient analysis approach. Using land-use/cover change data, this study measured the evolution of spatiotemporal features of landscape patterns and ecosystem services value (ESV) with 1, 2, and $3 \mathrm{~km}$ buffer-zone scales in Wuhan, China. Econometric models were then used to analyze the impacts of landscape patterns on ecosystem services at different bufferzone scales. The results demonstrated that rapid urbanization in Wuhan has led to significant changes in landscape patterns, and the landscape pattern metrics exhibited significant spatial heterogeneity. The ESV in Wuhan exhibited a steady decline during the study period. Hydrological regulations and waste treatment functions contributed to the largest proportion of ESV, and raw material production functions contributed to the lowest proportion. Landscape pattern metrics exerted a significant influence on ESV; however, this influence varied greatly. The results of this study provide a new understanding of the influence mechanism of landscape patterns on ecosystem services at 1,2, and $3 \mathrm{~km}$ buffer-zone scales. These findings are critical for facilitating landscape planning and regional sustainable development.
\end{abstract}

Keywords: landscape pattern metric; ecosystem services value; econometric model; buffer gradient analysis approach; Wuhan; China

\section{Introduction}

Rapid urbanization in metropolises has intensified changes in landscape patterns and ecosystem functions [1-3]. Landscape pattern evolution affects material circulation, energy flow, and information transmission in ecosystems [4]. Exploring the influence mechanism of landscape patterns on ecosystem services is vital for environmental sustainability planning [5]. Existing studies have proved that many metropolises are expanding outward in a circular pattern [6-8]. Such urban sprawl has been widely discussed from the perspective of concentric partitioning [7,9-12]. Within this body of literature, gradient analysis has been used to reveal the spatial distribution rule and the gradual evolution of the spatial characteristics of a research target along a certain direction, thereby revealing the concentric partitioning rules of urban sprawl [7]. From this point of view, the evolution characteristics 
and interaction mechanisms between landscape pattern metrics and ecosystem services should be explored with a multiscale buffer gradient analysis approach. Although previous studies have investigated the interaction mechanism of landscape pattern metrics on ecosystem services at multiple scales [13-16], few studies have explored the relationships between landscape patterns and ecosystem services using a multiscale buffer gradient analysis approach.

With the acceleration of urbanization and industrialization in metropolises, changes in natural and human landscape patterns have become increasingly drastic. Consequently, the degradation of ecosystem services in many cities has accelerated [17]. In this context, Wuhan, one of the national central cities of China undergoing rapid urbanization, was selected as a case study to analyze the impact of landscape pattern metrics on ecosystem services. In addition to being the geographical center of the country, Wuhan is also the largest metropolis and the economic center of central China. It is also the largest water, land, and air transportation hub in inland China, as well an important shipping center in the middle reaches of the Yangtze River [6]. Wuhan has an extensive network of rivers, lakes, and ports, where hundreds of mountains and numerous rivers and lakes form a particularly distinctive ecosystem $[18,19]$. Wuhan, one of three intelligence-intensive areas in China, is a core city in the Yangtze River Economic Belt, a strategic pivot point for the development of central China, and a comprehensive innovation and reform experimental zone. Its rapid urban expansion has resulted in drastic changes in the spatial structures and features of the landscape, and these changes have contributed to ecosystem degradation.

With increasing urbanization in Wuhan, construction has expanded outward in a circular form, and urban expansion now occupies a large amount of what was formally natural landscape [7]. At the same time, the increased intensity of human activities has had an impact on the landscape pattern in the marginal area, and the degree of landscape fragmentation in this area has increased. Analyzing the interactions between landscape patterns and ecosystem services at the buffer-zone scales can provide a new perspective on their relationships. In addition, Wuhan aims to build itself into a national central city with the following four functions: a national economic center, a high-tech innovation center, a trade and logistics center, and an international exchange center. In this context, its central resource integration shows a more obvious trend, and the original edge areas of the city center are expected to show a gradient pattern. Therefore, where the trends of resource and central area integration are more apparent, the original gradient pattern of the central urban and fringe areas is more intense. Understanding these relationships at buffer-zone scales can help to clarify the rules of landscape pattern evolution and to build a healthy and stable landscape ecosystem.

Previous studies have used gradient analysis methods to analyze the changes in landscape patterns [20-22] and ecosystem services globally [23-29]. A multiscale buffer gradient analysis approach can be used to effectively explore the differences among landscape patterns and ecosystem services between urban, suburban, and rural areas that are different distances from the city center [29-32]. Gradient analysis can be used to analyze the spatial structure of a city and the changes in landscape pattern characteristics and ecosystem services that take place in the process of urbanization. This, in turn, can provide references for the sustainable use of land resources and for effective land-use planning, management, and decision making. To explore the spatial gradient effect of the landscape pattern on ecosystem services in different periods, the current study applies the buffer gradient analysis method to analyze the spatiotemporal evolution characteristics of the landscape pattern and ecosystem services according to the spatial layout of Wuhan [6-8,33,34]. The buffer gradient analysis method is based on a series of equidistant buffer zones established outward from the center of a circle that is used as the research unit to describe the spatial heterogeneity of the landscape pattern and ecosystem services [35].

Previous studies concerning the interaction mechanism between landscape patterns and ecosystem services have been conducted at the grid [36], watershed [37], and administrative region scales [9]. However, few studies have explored this phenomenon at 
buffer-zone scales [38]. Compared with previous research scales, the buffer-zone scale can better reveal the spatial heterogeneity characteristics of the landscape pattern and ecosystem services in a certain direction, and it can effectively demonstrate the influence of urban expansion on surrounding elements $[7,12,39]$. What the spatial distribution characteristics of the landscape pattern and ecosystem services at the buffer-zone scales are and how the landscape pattern affects ecosystem services at the buffer-zone scales need to be further explored. Therefore, it is necessary to explore the impact mechanism of the landscape pattern on ecosystem services based on the buffer-zone scale.

Exploring the relationship between landscape patterns and ecosystem services value (ESV) can provide a scientific basis for landscape planning and ecological protection. To reveal the spatiotemporal variation characteristics of the landscape pattern and ecosystem services in different sections outside of the city center, this study estimated the landscape pattern and ecosystem services in Wuhan from 2000 to 2015 at the buffer-zone scale, based on land-use/cover change data. Then, the influencing mechanism of the landscape pattern on ecosystem services was analyzed using the econometric model. The objectives of this study are as follows: (1) to explore the spatiotemporal features of landscape pattern metrics using Fragstats v4.2.1 software (Oregon State University, Corvallis, OR, USA), (2) to estimate the spatiotemporal evolution features of ecosystem services using the benefits transfer method, and (3) to analyze the impact of landscape patterns on ecosystem services based on non-spatial panel regression models at 1,2, and $3 \mathrm{~km}$ buffer-zone scales in Wuhan from 2000 to 2015. The remainder of this paper is organized as follows. Section 2 presents a literature review of the gradient analysis approach and the impacts of the landscape pattern on ESV. Section 3 describes the research area, methods, and data sources. Section 4 presents the research findings. Section 5 summarizes these findings and presents the policy implications and limitations of the study. Finally, Section 6 summarizes the conclusions of the study.

\section{Literature Review}

\subsection{Gradient Analysis Approach}

Sokolow [40] first used the gradient analysis method to analyze landscape changes from urban to rural areas. Whittaker [41] applied the gradient analysis method to vegetation analysis. McDonnell [42] proposed that the landscape pattern would affect the structure and function of an ecosystem. Subsequently, the gradient analysis method has been applied in ecological studies and has been widely used to study the impact of urbanization on vegetation distribution and landscape ecology [21,27,28,42-45].

Geographic information system (GIS)-based gradient analysis has proved to be a highly effective method for analyzing the evolution of landscape patterns and ecosystem services. Gradient analysis methods, such as the cross-section method and buffer gradient analysis methods, are commonly used to analyze changes in landscape patterns and ecosystem services [30,42,46-48]. The cross-section method focuses on the analysis of changes in elements in several set directions, whereas the buffer gradient analysis approach is suitable for studying the macroscopic form of the agglomeration distribution of elements that can be used to study the structure of an urban circle layer [18]. Starting from the center of the study area, the circular buffer zone with equal step lengths is divided using transects $[19,20,31]$. The buffer gradient analysis approach can display the distribution rule of the research target on the circle layer. Therefore, it can be used to study gradient change in the landscape patterns and ecosystem services of the "agricultural landscape-suburban landscape-urban landscape" caused by urbanization, especially in metropolises $[22,49,50]$.

In terms of urban planning and form, Burgess [33] proposed the theory of concentric zones that focuses on the functional zoning of an urban space. The gradient analysis approach has proved to be a useful tool for analyzing urban expansion and its impact on the landscape as the distance from the city center increases [22,32,46,47,51-53]. For example, Yeh and Huang [47] analyzed the change characteristics of landscape diversity along the urban-to-rural gradient using the buffer gradient analysis method. Li et al. [51] 
analyzed the urban expansion characteristics of Shanghai using the buffer gradient analysis method. Kong et al. [46] used the gradient analysis method to analyze the spatiotemporal evolution of urban green spaces in Jinan. In addition, previous empirical studies investigated ecosystem services on the "urban-rural" gradient [23,29,43,54-56]. For example, Ou et al. [48] analyzed the supply-demand surplus of ecosystem services in the three gradient zones of the Yangtze River Delta using the gradient analysis method. Luck et al. [22] used gradient analysis to analyze changes in the urban spatial landscape pattern of the Phoenix Metropolitan Area of the United States. Hutyra et al. [57] and Larondelle and Haase [58], respectively, analyzed the evolution of ecosystem services in Seattle, USA, and Europe using the gradient method.

\subsection{Impacts of Landscape Pattern on ESV}

As a crucial focus area within landscape ecology research, landscape pattern indexing is an important analytical method for studying land-use changes [58]. Additionally, landscape pattern research can reflect the impact of human activities on regional ecological patterns and the spatiotemporal response of the environment to land-use changes $[2,15,59,60]$. Ecosystem services are the ecological functions and utilities that humans depend on for survival, and they are formed and maintained by ecosystems and ecological processes [61]. Ecosystem services have gained increasing research attention in the field of ecology, particularly in terms of ecosystem assessments [62,63]. Dynamic changes in landscape patterns impact the material circulation and energy flow within a regional ecosystem, thus affecting the provision capacities of ecosystem services [59]. Previous studies have integrated ecosystem services and landscape patterns to explore the spatiotemporal distribution of ecosystems and regional resources, as well as ecological issues related to ecological processes $[4,64,65]$. In rapidly urbanizing areas, the expansion of developed land reduces the amount of cultivated land and therefore also reduces the supply capacity of ecosystem services and regional biodiversity. The expansion of traffic networks can intensify landscape fragmentation, damage habitats, and affect the ecosystem services balance [66]. Changes in landscape patterns can also lead to an increase in ecosystem services, such as those occurring through land consolidation engineering and afforestation projects. There are typically significant differences in the characteristics of landscapes among different buffer-zone areas. For example, supply services are mainly distributed in the peripheral areas of a metropolis, where agricultural land is dominant. In addition, previous studies have demonstrated that the provision capacity of biodiversity and aesthetic landscape services significantly increases from the core of the buffer zone and to outside the buffer zone [67-69].

Research on landscape pattern evolution [33,70,71], ESV estimation [62-64], and their interaction mechanisms in the context of rapid urbanization [16,37] has attracted transdisciplinary interest and has become a core area of landscape ecology. Recently, research has been conducted on the impact of landscape patterns on ESV [16,37,71]. For example, Su et al. [71] explored the relationships between landscape patterns and ecosystem services using a stepwise regression at the eco-regional level. Yushanjiang et al. [37] analyzed the relationships between 13 landscape patterns and nine types of subcategory ecosystem services in the Ebinur Lake Basin, Xinjiang, China, using multiple linear regression models. Liu et al. [16] identified the impact of landscape patterns on supplying services, regulating services, supporting services, and cultural services in the middle reaches of the Yangtze River Urban Agglomeration, China, using spatial regression models. To date, few studies have combined landscape patterns and ecosystem services to explore their evolution characteristics and interaction mechanism in metropolises at buffer-zone scales.

Multivariate regression, spatial regression analysis, multiple linear regression models, and Pearson correlation analysis are commonly used to measure the relationships between ecosystem services and landscape patterns [14,15,50,71,72]. However, few studies have utilized panel models to measure the multiscale interaction mechanism between ecosystem services and landscape patterns $[37,50,64,71]$. The existing literature has demonstrated 
that there are significant scale effects on the relationship between landscape patterns and ecosystem services $[15,37,64]$. Thus, the scale effects of landscape patterns on ecosystem services should be investigated. The impacts of landscape patterns on ecosystem services have been found to vary greatly across different study areas and at varying scales [50]. Some studies have discussed the difference in urban land density gradient changes in relation to whether Wuhan should be considered a single or multicenter city and whether to establish a regular buffer depending on its status [7]. The urban form has an important impact on regional land-use change, ecosystem services, and landscape patterns [72]. It is therefore necessary to select appropriate buffer-zone scales to analyze the gradient change among landscape patterns and ecosystem services.

\section{Materials and Methods}

\subsection{Study Area}

Wuhan $\left(29^{\circ} 58^{\prime}-31^{\circ} 22^{\prime} \mathrm{N}, 113^{\circ} 41^{\prime}-115^{\circ} 05^{\prime} \mathrm{E}\right)$, the capital of Hubei Province, is the largest city in central China, with an area of $8,494 \mathrm{~km}^{2}$. It is located in the middle and lower reaches of the Yangtze River and east of the Jianghan Plain (Figure 1). To better display the landscape characteristics of different districts in Wuhan, we provide some photographs of Wuhan (Figure 2). The Yangtze River and the Han River confluence in Wuhan, forming the spatial pattern of Wuchang District, Hankou District, and Hanyang District. As the core city of the Wuhan urban agglomeration, Wuhan benefits from an extensive, interconnected road network that greatly promotes the socioeconomic development of the city. The city's high-speed rail network extends across half of China, and it is the only city in central China with direct flights to five continents. The population of Wuhan increased from 8.048 million in 2000 to 10.608 million in 2015. Wuhan's gross domestic product (GDP) increased from CNY 115.34 billion in 2000 to CNY 1054.77 billion in 2015, and its per capita GDP increased from CNY 14,473 in 2000 to CNY 100,714 in 2015 [73]. Increasingly, rapid economic development and urbanization in Wuhan have led to the rapid outward expansion of construction land; this has had a substantial impact on ecosystem services and landscape patterns. Therefore, it is of great importance that we study the impact of landscape patterns on ecosystem services in Wuhan at the buffer-zone scale.

\subsection{Data Sources}

Wuhan's land-use data for 2000, 2005, 2010, and 2015 were sourced from the Resource and Environmental Science Data Center of the Chinese Academy of Sciences (http:/ / www. resdc.cn). The spatial resolution of the land-use data in this study was $30 \times 30 \mathrm{~m}$. The Landsat Thematic Mapper/Enhanced Thematic Mapper and Landsat 8 remote sensing images were the primary data sources. Liu et al. generated a land-use dataset with a long time series with 5-year intervals using human visual interpretation with a high degree of accuracy ( $\geq 90 \%$ ) [74-76]. Based on previous studies [77], ArcGIS 10.3 tools were adopted in the present study to reclassify land-use/cover change data into seven categories: cultivated land, construction land, water area, wetland, unused land, forestland, and grassland (Figure 3). In addition, the per-unit area yields of wheat, rice, corn, and soybean were used to calculate the ESV; the data were derived from the Wuhan Statistical Yearbook from 2000 to 2016, and the grain price data were obtained from the 2016 China Agricultural Product Price Survey Yearbook and other statistical data.

The selection of the buffer object and buffer distance is the key in the buffer gradient analysis. In a single-center ring city, the city center is generally chosen as the buffer object. Thus, the districts of Hankou, Hanyang, and Wuchang were considered as the research centers because Wuhan is divided into three towns. According to the "Ecoframework Planning of Wuhan Urban Development Area", the control width of the ecological corridors between the six new towns is generally required to be $0.5-1 \mathrm{~km}$. Considering the scope of the study area, $1 \mathrm{~km}$ was selected as the basic buffer distance. Scales of 1, 2, and $3 \mathrm{~km}$ were selected in this study (Figure 4) to explore the relationship between landscape patterns and ecosystem services at different buffer-zone scales $[6,19,78]$. 

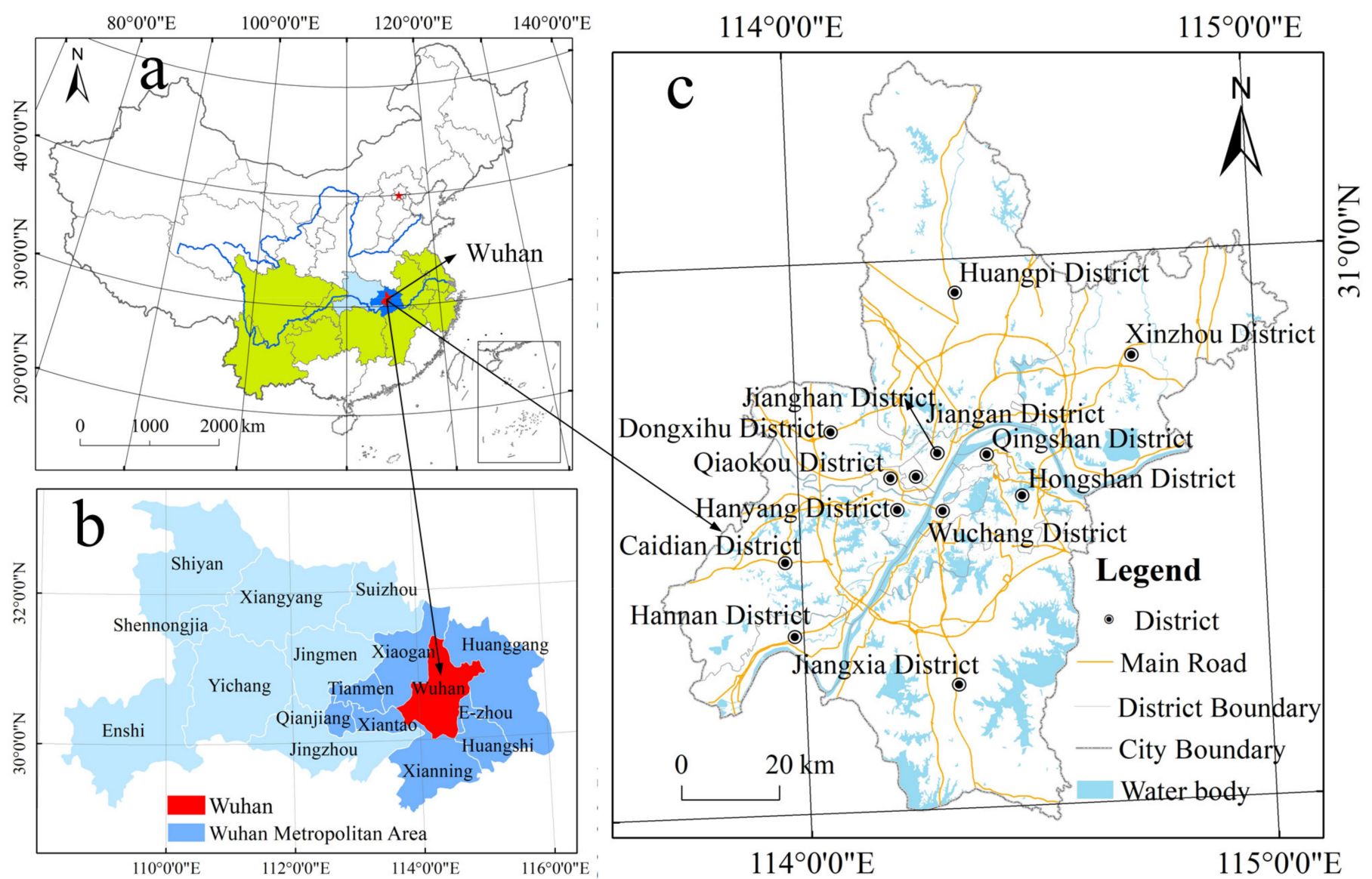

Figure 1. Location of the study area. (a) is the location of Wuhan in China; (b) is the location of Wuhan in Hubei Province; (c) is the different districts in Wuhan.

\subsection{Methods}

\subsubsection{Landscape Pattern Metrics}

Landscape pattern metrics can highly condense landscape spatial pattern information using a simple quantitative index that reflects their structural composition and spatial configuration features [79]. These can then be used to evaluate and compare changes in varying or same landscapes across different periods or under different planned designs [72,80]. Therefore, this study used landscape pattern metrics to characterize the landscape pattern features in Wuhan. A series of landscape pattern metrics (including number of patches $(\mathrm{NP})$, patch density (PD), largest patch index (LPI), patch edge density (ED), landscape shape index (LSI), area-weighted mean patch area (AREA_AM), area-weighted mean patch shape index (SHAPE_AM), area-weighted mean patch fractal index (FRAC_AM), contagion index (CONTAG), percentage of landscape (PLAND), interspersion juxtaposition index (IJI), patch cohesion index (COHESION), landscape division index (DIVISION), splitting index (SPLIT), Shannon diversity index (SHDI), and aggregation index (AI)) were selected at both the class and the landscape level to measure the landscape pattern features of Wuhan. However, some landscape pattern metrics were redundant; therefore, we conducted a multicollinearity test using SPSS19.0 and finally selected PD, LSI, AREA_AM, FRAC_AM, CONTAG, IJI, DIVISION, SPLIT, and SHDI to measure the landscape pattern characteristics of Wuhan. The equation of the landscape pattern metrics was adopted from McGarigal (1995) [79]. To calculate the landscape pattern indices at different buffer scales, Fragstats v4.2.1 was used to analyze the landscape pattern metrics of the study area. We first used ArcGIS10.3 software to cut out the land-use raster data of different buffer zones in batches, and then calculated landscape pattern metrics in batches in Fragstats v4.2.1. 
a. Jiang'an District

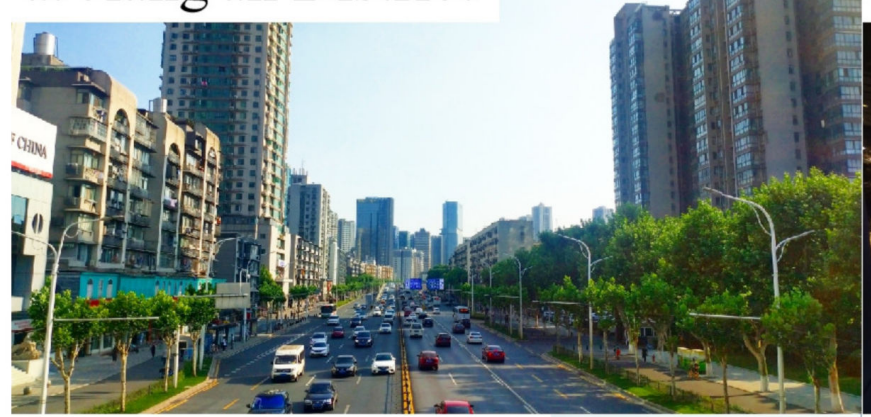

c. Wuchang District

\section{d. Hongshan District}

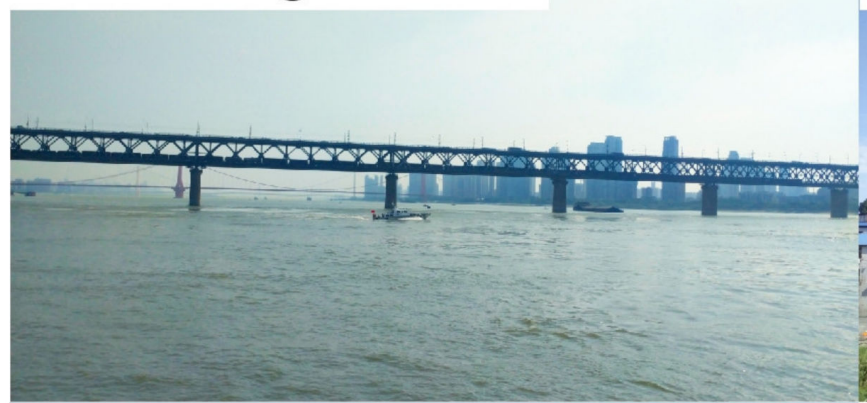

e. Wuchang District

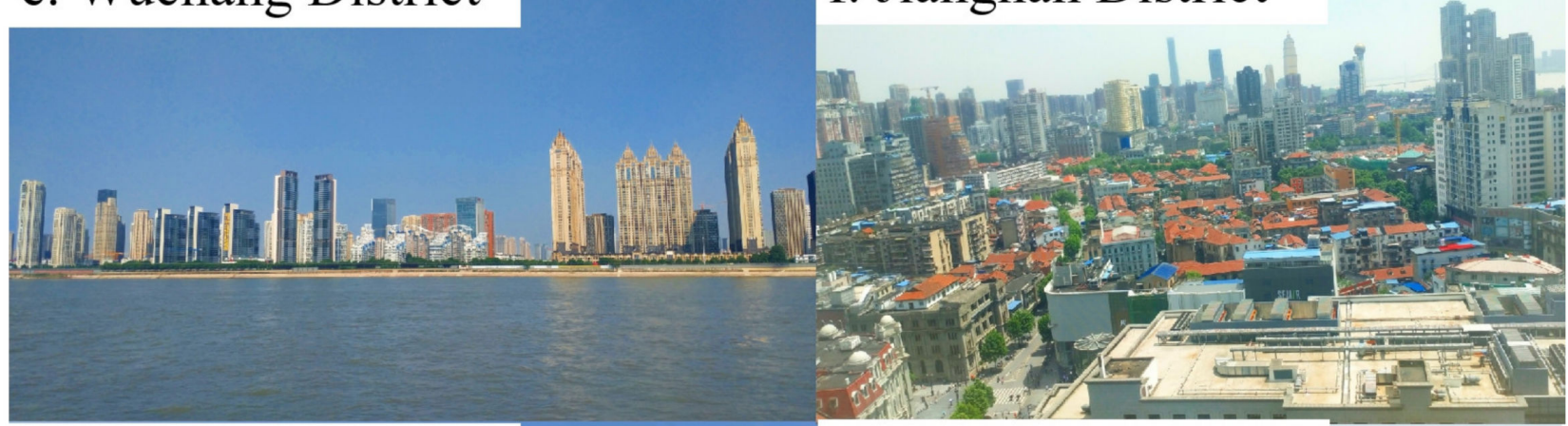

g. Hongshan District

h. Huangpi District

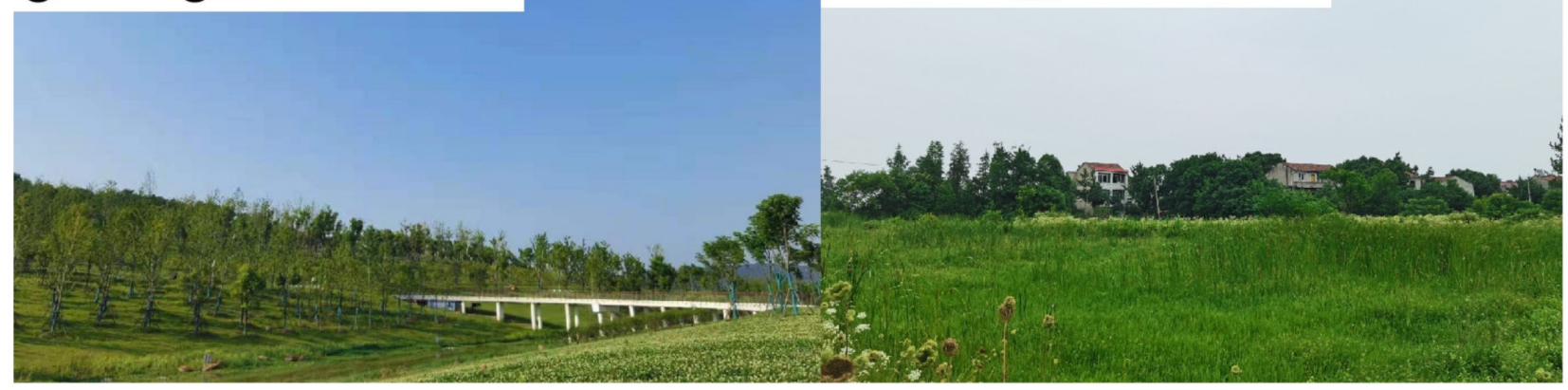

Figure 2. Photographs of different district in Wuhan $(\mathbf{a}-\mathbf{h})$. These photographs were taken by the authors:(a) is the urban landscape (streets) in the Jiang' an District; (b) is the urban landscape in Hongshan District (Optics Valley Square); (c) is the water landscape in Wuchang District (Wuhan Yangtze River Bridge); (d) is the transition zone between urban and rural areas in Hongshan District; (e) is the urban and water landscape of Wuchang District; (f) is the urban landscape in Jianghan District; (g) is the natural landscape in Hongshan District (Jigong Mountain Park); (h) is the rural area in Huangpi District. 


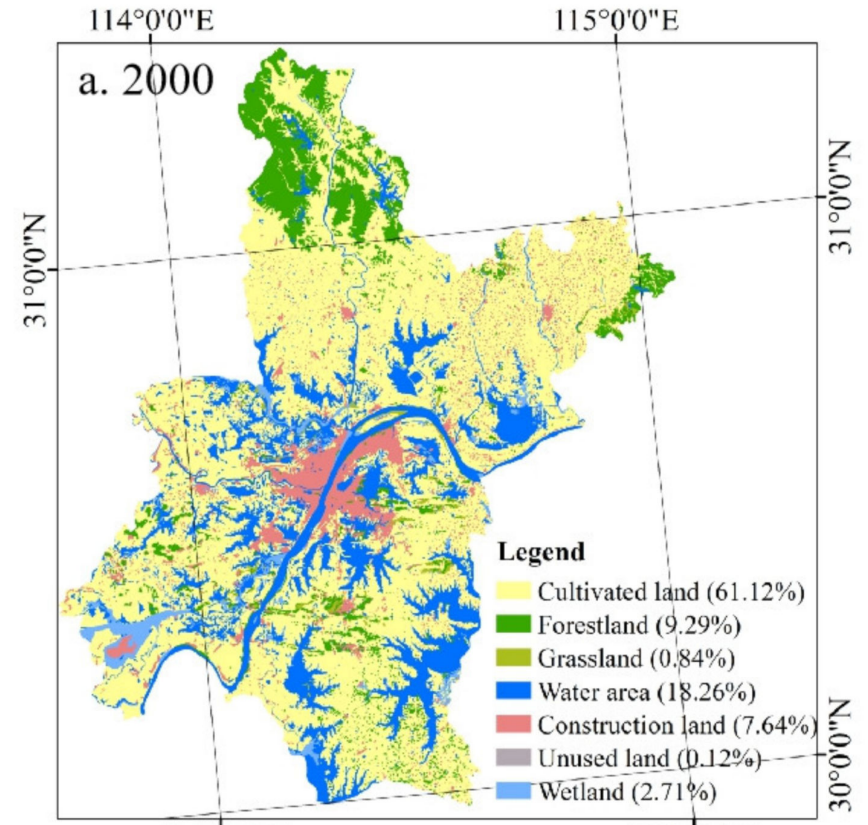

$114^{\circ} 0^{\prime} 0^{\prime \prime} \mathrm{E}$ $115^{\circ} 0^{\prime} 0^{\prime \prime E}$

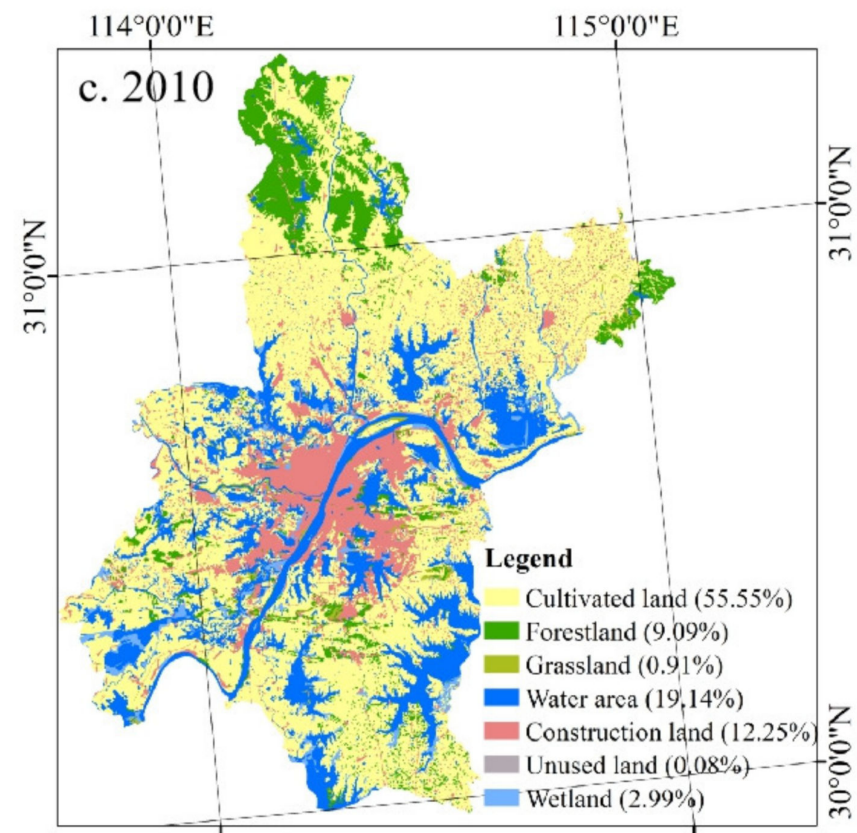

$114^{\circ} 0^{\prime} 0^{\prime \prime} \mathrm{E}$ $115^{\circ} 0^{\prime} 0^{\prime \prime} \mathrm{E}$

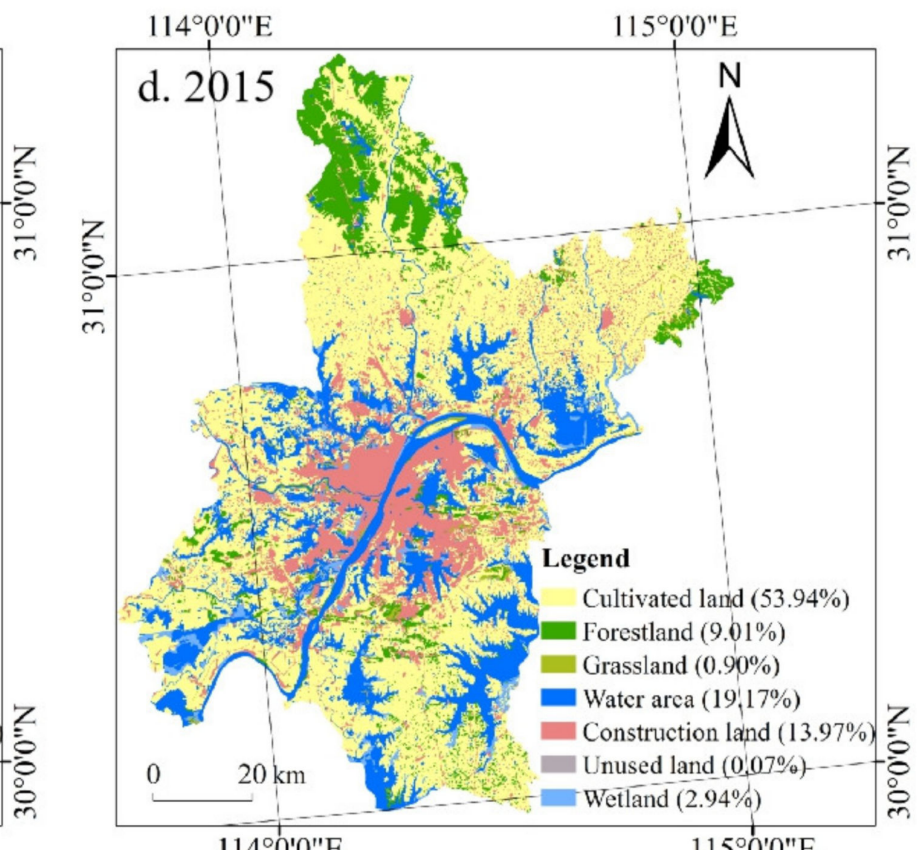

Figure 3. Spatial pattern of land use in Wuhan from 2000 to 2015. (a) is the spatial pattern of land use in Wuhan in 2000; (b) is the spatial pattern of land use in Wuhan in 2005; (c) is the spatial pattern of land use in Wuhan in 2010; (d) is the spatial pattern of land use in Wuhan in 2015. 


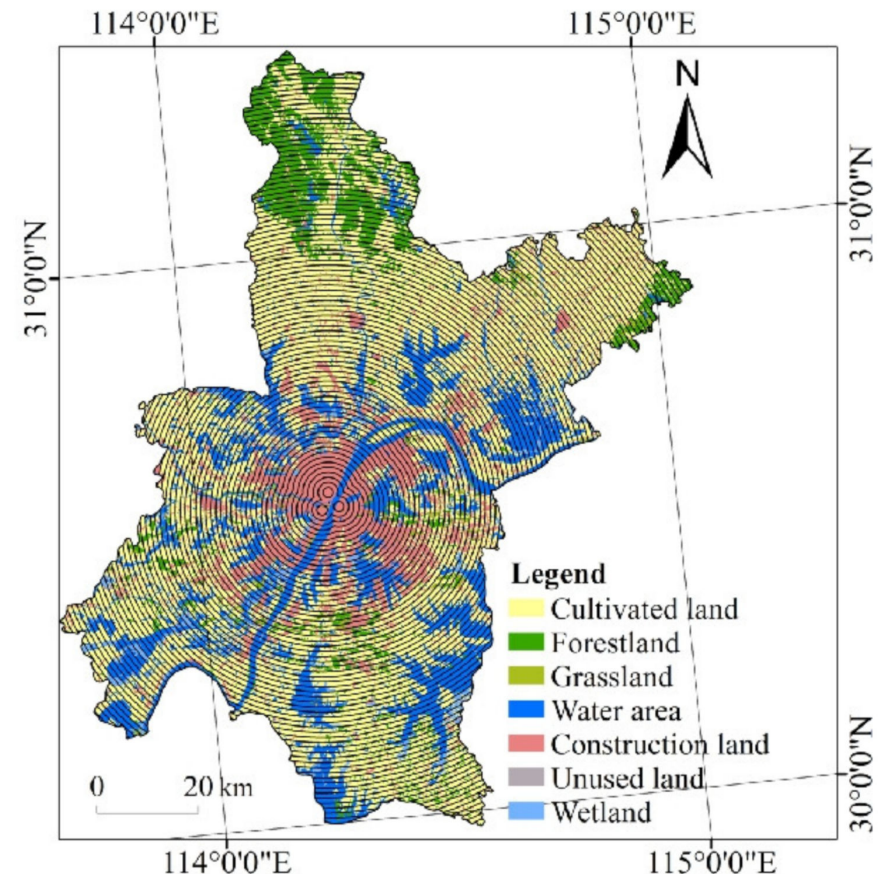

a. $1 \mathrm{~km}$ buffer zone scale

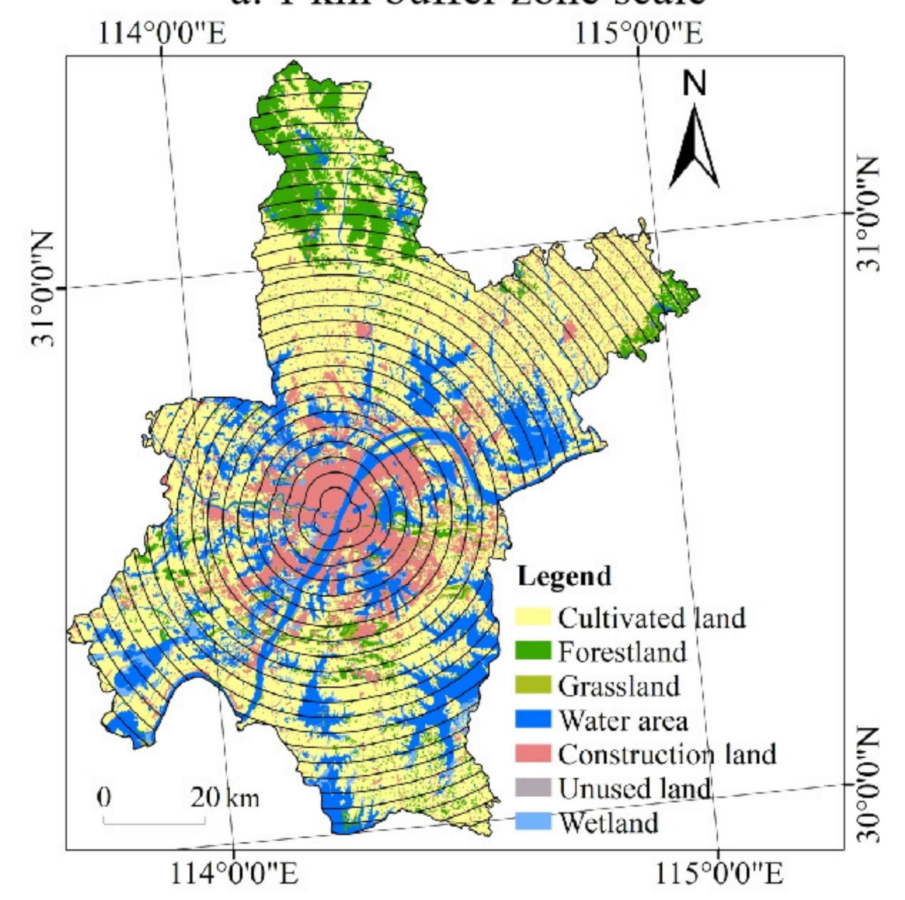

\section{c. $3 \mathrm{~km}$ buffer zone scale}

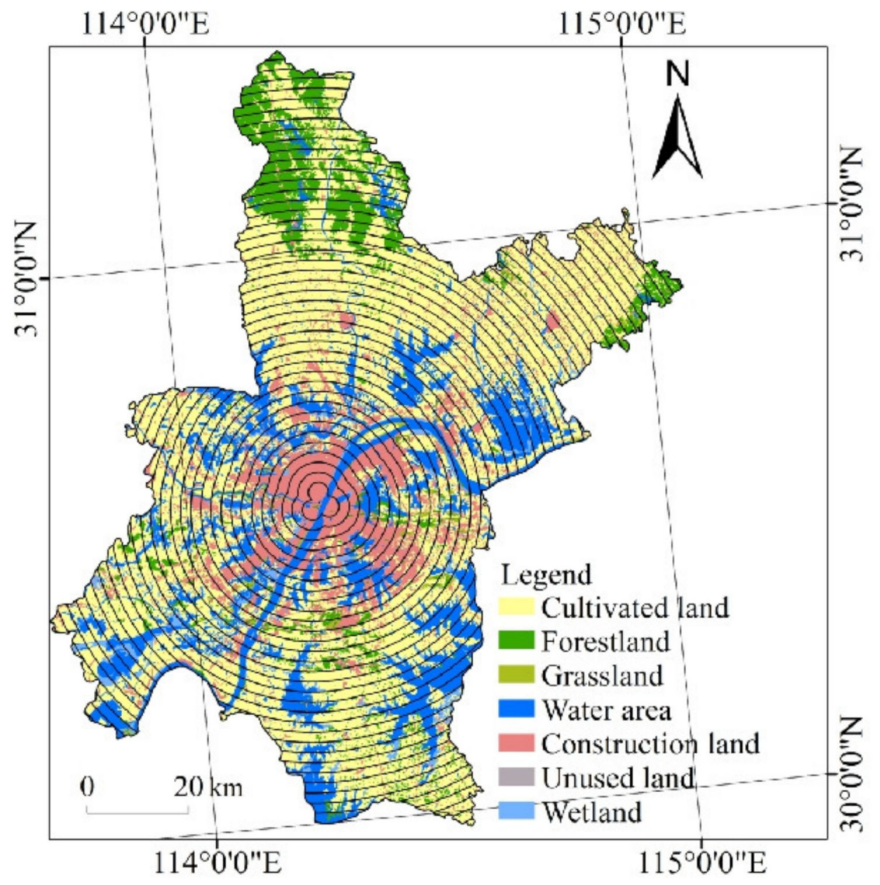

b. $2 \mathrm{~km}$ buffer zone scale

Figure 4. 1, 2, and $3 \mathrm{~km}$ buffer-zone scales used in this study (a-c), (a) is $1 \mathrm{~km}$ buffer zone scale in Wuhan; (b) is $2 \mathrm{~km}$ buffer zone scale in Wuhan; (c) is $3 \mathrm{~km}$ buffer zone scale in Wuhan.

\subsubsection{Measurement of ESV}

ESV has been widely accepted by the scientific community as one of the primary indicators for evaluating changes in ecosystems [81]. Based on the benefit transfer method proposed by Costanza et al. [82], in this study, we used the ESV equivalent table constructed by Xie et al. [83] to measure the ESV of Wuhan, which was based on Chinese ecosystems and expert knowledge. The present study primarily considered the yield and price of wheat, rice, corn, and soybeans in Wuhan and calculated their combined ecosystem services 
equivalent value as $\left.322.676 \mathrm{USD} /\left(\mathrm{hm}^{2} \cdot \mathrm{a}\right)\right)$. Using the ESV equivalent table proposed by Xie et al. [83] and the equivalent value of ecosystem services in Wuhan, the Wuhan ESV equivalent table was created (Table 1). As land-use types and ecosystems do not perfectly correspond with each other, the ecosystem closest to the land-use type was assigned to the corresponding ecosystem services equivalent coefficient [62]. Although previous studies have argued that construction land cannot provide ecosystem services, others countered that it could (e.g., recreational functions); based on this, the present study considers that construction land can provide ecosystem services [62,84-86]. The specific calculation equations are as follows:

$$
\begin{gathered}
E S V=\sum_{i=1}^{m} \sum_{j=1}^{n} L A_{j} E V_{i j} \\
A E S V=\sum_{i=1}^{m} \sum_{j=1}^{n} L A_{j} E V_{i j} / \sum_{j=1}^{n} L A_{j}
\end{gathered}
$$

where ESV is the ecosystem services value; $A E S V$ is the average ESV; $L A_{j}$ is the area of the $j$-th land-use type; and $E V_{i j}$ is the $i$-th ecosystem function of the $j$-th land-use type.

\begin{tabular}{|c|c|c|c|c|c|c|c|c|}
\hline Category & Subcategory & Forestland & Grassland & $\begin{array}{c}\text { Cultivated } \\
\text { Land }\end{array}$ & Wetland & Water Area & $\begin{array}{c}\text { Unused } \\
\text { Land }\end{array}$ & $\begin{array}{c}\text { Construction } \\
\text { Land }\end{array}$ \\
\hline \multirow{3}{*}{$\begin{array}{l}\text { Supplying } \\
\text { services }\end{array}$} & Food production & 106.483 & 138.751 & 322.676 & 116.163 & 171.018 & 6.454 & 3.227 \\
\hline & Raw material & 961.576 & 116.163 & 125.844 & 77.442 & 112.937 & 12.907 & 0 \\
\hline & Gas regulation & 1393.962 & 484.015 & 232.327 & 777.650 & 164.565 & 19.361 & -780.877 \\
\hline \multirow{3}{*}{$\begin{array}{c}\text { Regulating } \\
\text { services }\end{array}$} & $\begin{array}{l}\text { Climate } \\
\text { regulation }\end{array}$ & 1313.293 & 503.375 & 312.996 & 4372.265 & 664.713 & 41.948 & - \\
\hline & $\begin{array}{l}\text { Hydrological } \\
\text { regulation }\end{array}$ & 1319.746 & 490.468 & 248.461 & 4336.770 & 6056.635 & 22.587 & -2423.300 \\
\hline & Waste treatment & 555.003 & 425.933 & 448.520 & 4646.540 & 4791.744 & 83.896 & -793.784 \\
\hline \multirow{2}{*}{$\begin{array}{l}\text { Supporting } \\
\text { services }\end{array}$} & $\begin{array}{l}\text { Soil formation } \\
\text { and retention }\end{array}$ & 1297.159 & 722.795 & 474.334 & 642.126 & 132.297 & 54.855 & 6.454 \\
\hline & $\begin{array}{c}\text { Biodiversity } \\
\text { protection }\end{array}$ & 1455.270 & 603.405 & 329.130 & 1190.676 & 1106.780 & 129.071 & 109.710 \\
\hline \multirow{2}{*}{$\begin{array}{l}\text { Cultural } \\
\text { services }\end{array}$} & $\begin{array}{l}\text { Recreation and } \\
\text { culture }\end{array}$ & 671.167 & 280.728 & 54.855 & 1513.352 & 1432.683 & 77.442 & 3.227 \\
\hline & Total ESV & 9073.660 & 3765.633 & 2549.143 & 17672.985 & 14633.373 & 448.520 & -3875.343 \\
\hline
\end{tabular}

Table 1. ESV per land-use type in Wuhan after correction. [USD/(hm² $\cdot \mathrm{a})]$.

Notes: USD 100 could be exchanged for CNY 622.84 in 2015.

\subsubsection{Econometric Model}

To measure the impact of landscape patterns on ecosystem services, a set of non-spatial panel models was adopted in this study [87]. Commonly used non-spatial panel models include the mixed-, fixed-, and random-effects models [88]. The mixed-effects model assumes that there is no significant difference in the time at which different individual panel data were collected, and that there is no significant difference between different sections. A model is typically called a mixed model if certain coefficients are random and others are fixed. The application of the fixed-effects model assumes that the direction and effects of the research results are similar; that is, the results of all independent studies are similar, and there is no significant difference in the consistency test. Therefore, the fixed-effects model is suitable for studies with little or no difference between independent studies. The random-effects model is a generalization of the classic linear model; the original regression coefficient is regarded as a random variable, which is typically assumed to originate from a normal distribution. From the above description, it can be seen that the difference between the fixed-effects model and the random-effects model lies in its basic assumption, i.e., whether individual variables that do not change over time are related to 
predicted or independent variables [89]. The specific form of the non-spatial panel data model is as follows:

$$
\begin{aligned}
A E S V_{i t}= & \alpha+\beta_{1} P_{i t}+\beta_{2} L_{S I}+\beta_{3} A R E A \_A M_{i t}+\beta_{4} F R A C_{-} A M_{i t}+\beta_{5} \text { CONTAG }_{i t} \\
& +\beta_{6} I_{i t} I_{i t}+\beta_{7} D I V I S I O N_{i t}+\beta_{8} S P L I T_{i t}+\beta_{9} S H D I_{i t}+\delta_{i}+\eta_{i}+\varepsilon_{i t}
\end{aligned}
$$

where $A E S V_{i t}$ represents the average ecosystem services of the $i$-th unit at time $t ; \alpha$ is the intercept term; $\beta$ is the regression coefficient; $\varepsilon_{i t}$ are the random disturbance terms; $\delta_{i}$ represents the individual effect; and $\eta_{i}$ denotes the time effect. In panel models, the $F$ test is typically used to select either the mixed-effects or the fixed-effects model, and the Hausman test is typically adopted to select either the fixed- or random-effects model.

\section{Results}

\subsection{Landscape Patterns in Wuhan from 2000 to 2015}

Figures 5 and 6 illustrate the changes in landscape pattern metrics at the landscape and class levels from 2000 to 2015, respectively. In Wuhan, at the landscape level, the PD, LSI, SHDI, DIVISION, and SPLIT indices increased during the study period, whereas AREA_AM, CONTAG, and FRAC_AM decreased. The IJI index increased in volatility during the study period (Figure 4). Significant changes occurred in the class-level landscape pattern index in Wuhan (Figure 5). Specifically, the PD of different landscape classes increased, the highest of which was construction land, and the most significant increase occurred for cultivated land. The LSI of construction land was the highest of all the landuse types; that of forestland, cultivated land, construction land, wetland, and grassland increased during the study period, and that of the water area and unused land decreased. The AREA_AM and FRAC_AM of cultivated land were significantly higher than those of other landscape types. In addition, the AREA_AM of forestland, cultivated land, wetland, unused land, and grassland decreased, whereas that of the other land-use types substantially increased. During the study period, only the IJI index of cultivated land decreased, whereas the IJI of the other landscape types significantly increased. The DIVISION index of cultivated land significantly increased, whereas the DIVISION index of the other landscape types did not significantly change. The SPLIT index of unused land was noticeably higher than that of the other landscape types, and the SPLIT index of cultivated land was the lowest.

Figures 7-9 illustrate the spatial patterns of landscape metrics in Wuhan in 2015 for buffer-zone scales of 1,2 , and $3 \mathrm{~km}$, respectively. The spatial distribution of the landscape pattern metrics exhibited significant spatial heterogeneity. Specifically, PD, LSI, DIVISION, IJI, SPLIT, and SHDI exhibited similar spatial patterns; that is, the core area of the buffers was low and, with the expansion of the buffer scale, these landscape pattern metrics increased and then significantly decreased. In contrast, AREA_AM, FRAC_AM, and CONTAG exhibited a higher value in the core area of the buffers, and they gradually decreased with an increase in the buffer, followed by an increasing and then decreasing trend. Wavy change patterns can be observed at different buffer-zone scales.

\subsection{ESV in Wuhan from 2000 to 2015}

In 2000, 2005, 2010, and 2015, the ESVs provided by Wuhan ecosystems were USD 4,532.341, 4,439.352, 4,394.293, and 4,293.343 million, respectively, indicating that the ESV supply capacity of ecosystems in Wuhan declined during the study period. The ESVs in Wuhan decreased by USD 92.988, 45.059, and 100.950 million during 2000-2005, 2005-2010, and 2010-2015, respectively. The ESV contributed by water area was the highest (>USD 2200 million), followed by cultivated land (>USD 1100 million USD). The ESV provided by construction land was negative, namely USD -253.817, -305.906, -406.938, and -463.885 million in 2000, 2005, 2010, and 2015, respectively. Among the subcategory ecosystem function types, the hydrological regulation and waste treatment functions were the highest, accounting for $24 \%$ of the ESV, whereas the raw material production function accounted for the lowest proportion (approximately 3.5\%) (Tables 2 and 3). During the study period, 
the food production, raw material production, gas regulation, hydrological regulation, and soil formation and retention functions decreased, whereas climate regulation, waste treatment, and biodiversity protection exhibited a decreasing trend during 2000-2005 and 2010-2015 and an increasing trend from 2005 to 2010. The recreation and culture functions increased during 2000-2010 and then decreased during 2010-2015. In 2000, 2005, 2010, and 2015, the average ESVs provided by Wuhan ecosystems were 5,289.073, 5,180.539, 5,127.915, and 5,010.089 USD $/ \mathrm{hm}^{2}$, respectively. We mapped the spatiotemporal distribution of the average ESVs at the 1,2, and $3 \mathrm{~km}$ buffer-zone scales. The average ESV in the core area of Wuhan was low, and the buffer zone of the low average ESV expanded outward from 2000 to 2015 (Figures 10-12). Additionally, the water area in Wuhan greatly influenced the average ESV of each buffer.
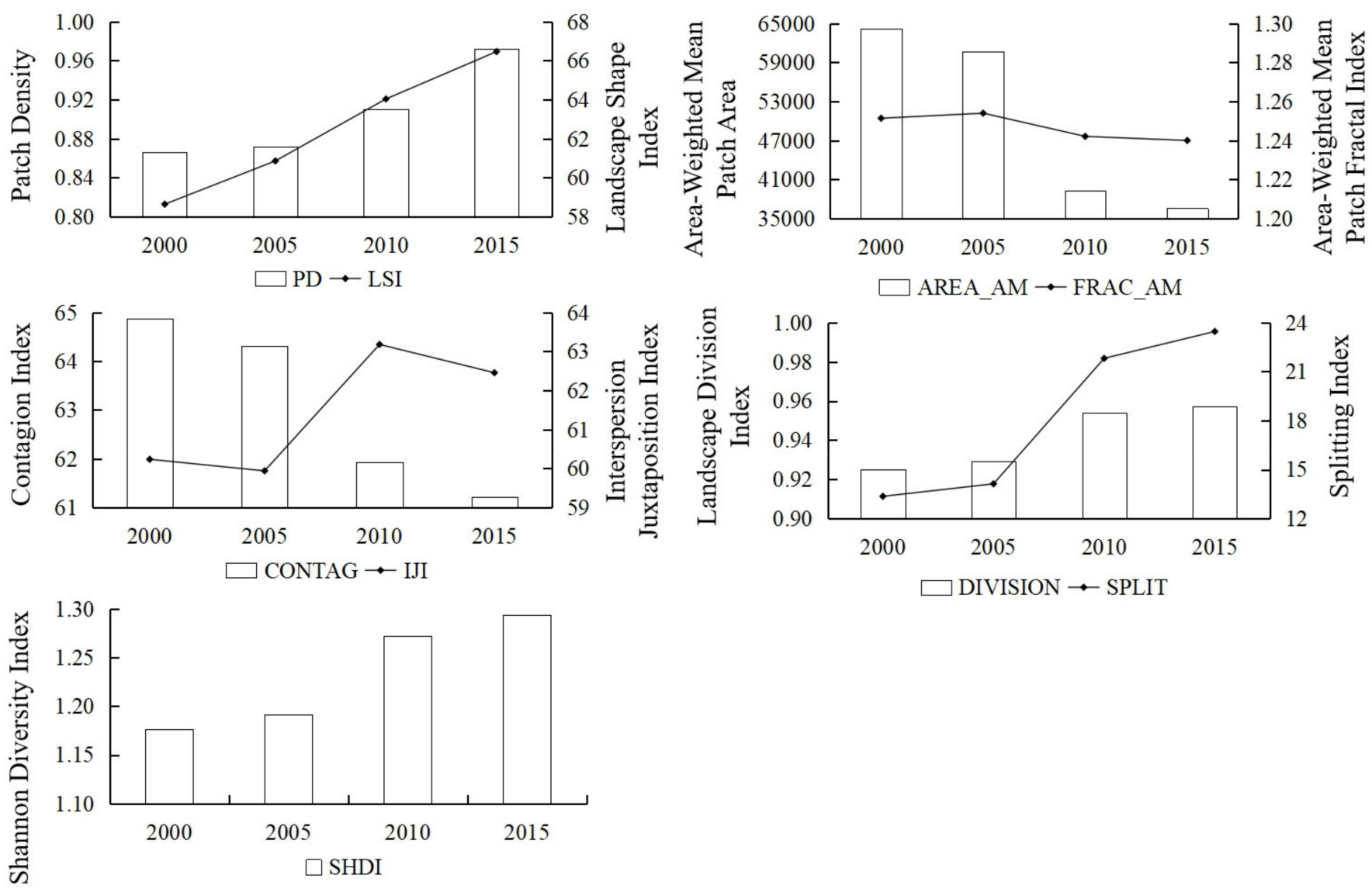

Figure 5. Change in the landscape pattern metrics of Wuhan from 2000 to 2015. 

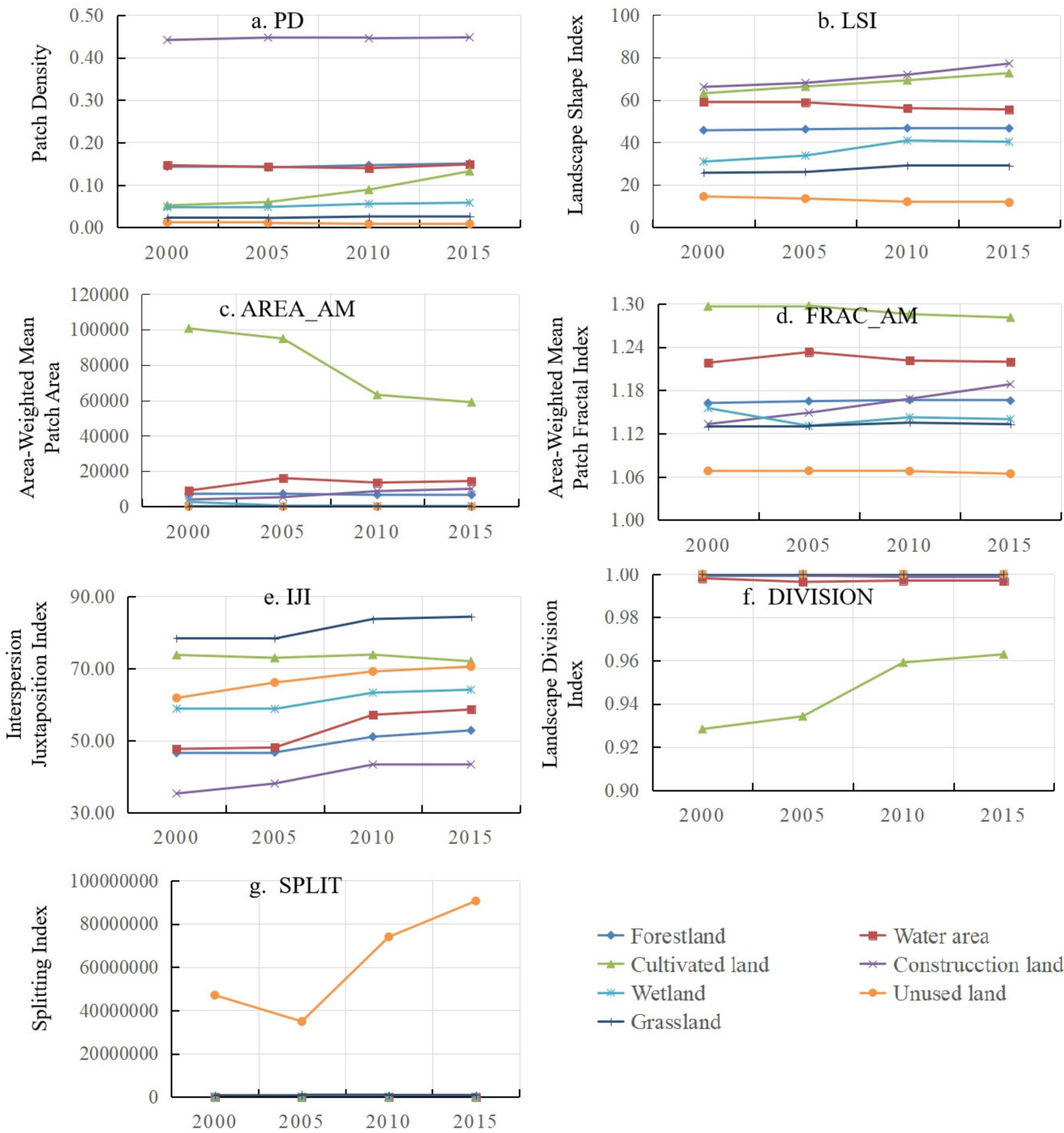
- Water area
* Construcction land
$\rightarrow$ Unused land

Figure 6. Landscape metrics of each land-use type in Wuhan from 2000 to 2015 (a-g). 

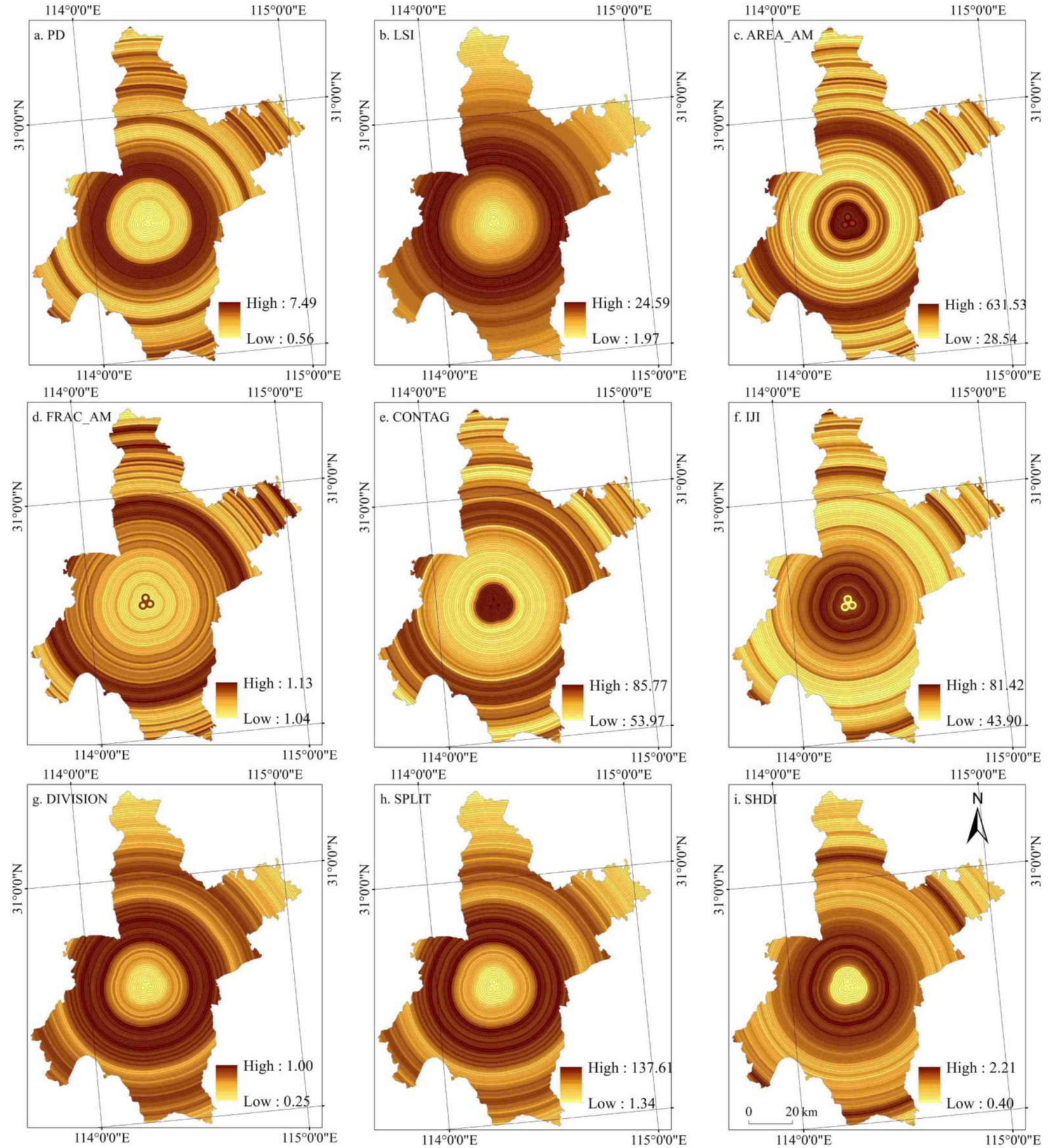

Figure 7. Landscape pattern index in Wuhan at the $1 \mathrm{~km}$ buffer scale in 2015 (a-i). 

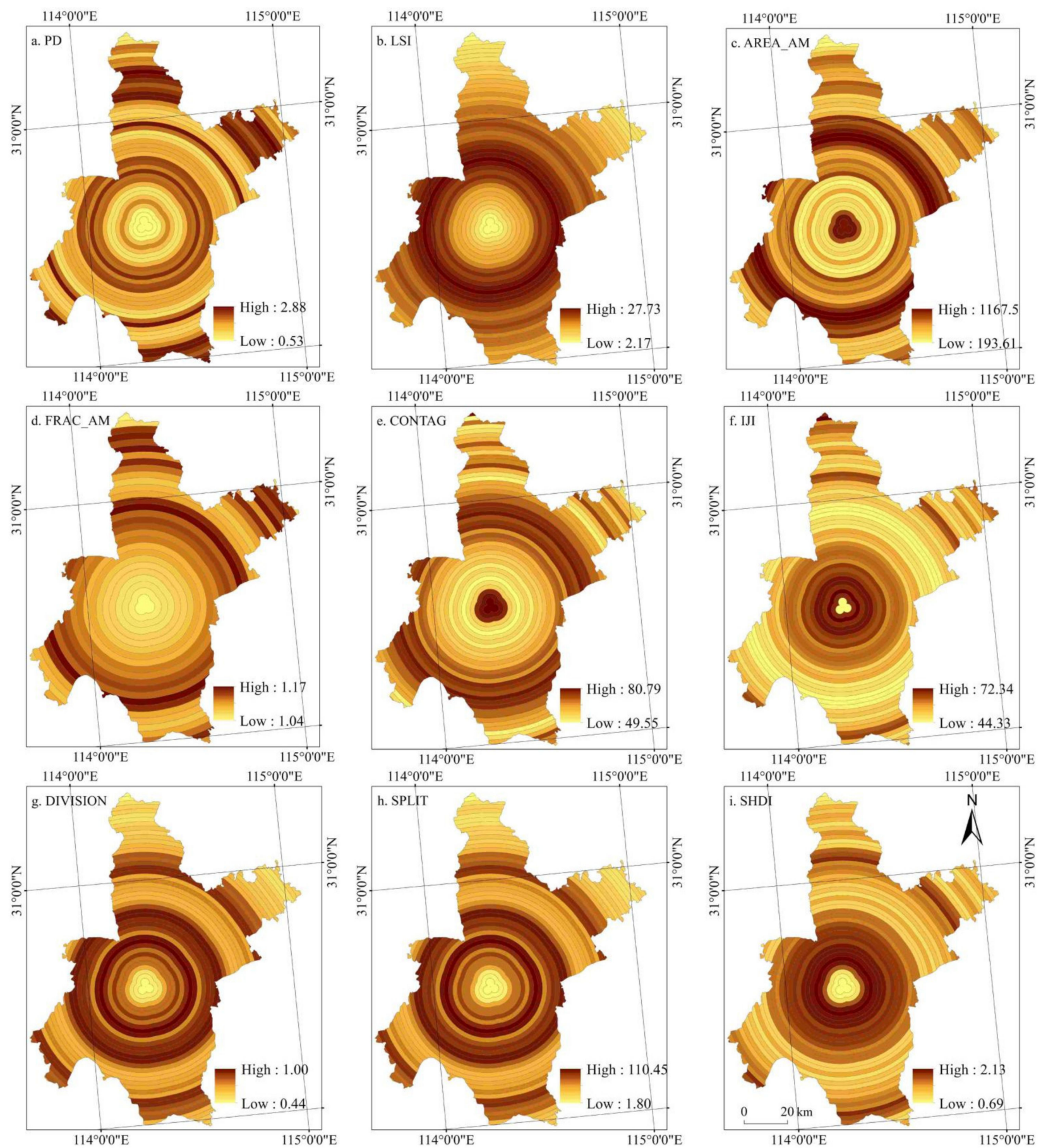

Figure 8. Landscape pattern index in Wuhan at the $2 \mathrm{~km}$ buffer scale in 2015 (a-i). 

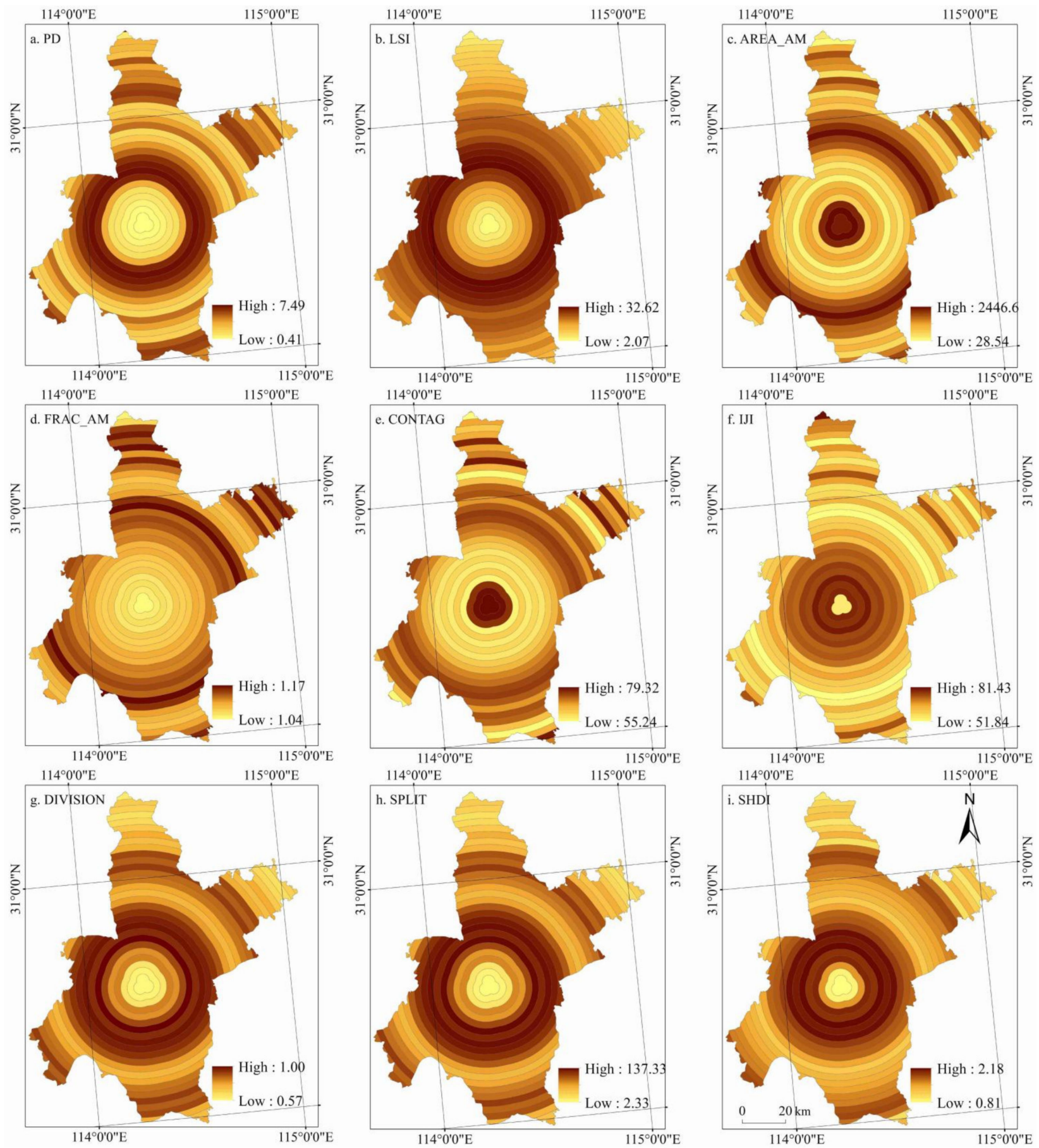

Figure 9. Landscape pattern index in Wuhan at the $3 \mathrm{~km}$ buffer scale in 2015 (a-i).

Table 2. ESV provided by different land-use types from 2000 to 2015 (million US\$).

\begin{tabular}{ccccc}
\hline Land-Use Types & $\mathbf{2 0 0 0}$ & $\mathbf{2 0 0 5}$ & $\mathbf{2 0 1 0}$ & $\mathbf{2 0 1 5}$ \\
\hline Cultivated land & 1335.110 & 1300.575 & 1213.313 & 1178.165 \\
Forestland & 722.118 & 716.493 & 706.551 & 700.760 \\
Grassland & 27.224 & 25.561 & 29.239 & 28.933 \\
Water area & 2290.105 & 2389.151 & 2399.735 & 2403.493 \\
Construction land & -253.817 & -305.906 & -406.938 & -463.885 \\
Unused land & 0.479 & 0.456 & 0.317 & 0.282 \\
Wetland & 411.123 & 313.022 & 452.076 & 445.594 \\
In total & 4532.341 & 4439.352 & 4394.293 & 4293.343 \\
\hline
\end{tabular}


Table 3. Different categories of ESVs from 2000 to 2015 (USD million).

\begin{tabular}{|c|c|c|c|c|c|}
\hline Category & Subcategory & 2000 & 2005 & 2010 & 2015 \\
\hline \multirow{3}{*}{$\begin{array}{c}\text { Supplying } \\
\text { services }\end{array}$} & Food production & 208.163 & 204.220 & 194.313 & 189.833 \\
\hline & Raw material & 162.766 & 160.748 & 156.187 & 153.828 \\
\hline & Gas regulation & 228.838 & 210.913 & 187.780 & 171.928 \\
\hline \multirow{3}{*}{$\begin{array}{c}\text { Regulating } \\
\text { services }\end{array}$} & Climate regulation & 477.870 & 452.820 & 476.028 & 469.397 \\
\hline & Hydrological regulation & 1128.758 & 1108.706 & 1074.553 & 1034.598 \\
\hline & Waste treatment & 1088.254 & 1077.613 & 1081.372 & 1062.655 \\
\hline \multirow{2}{*}{$\begin{array}{l}\text { Supporting } \\
\text { services }\end{array}$} & $\begin{array}{l}\text { Soil formation and } \\
\text { retention }\end{array}$ & 393.014 & 382.879 & 371.226 & 363.688 \\
\hline & Biodiversity protection & 500.791 & 497.514 & 498.231 & 494.165 \\
\hline \multirow[t]{2}{*}{ Cultural services } & Recreation and culture & 343.886 & 343.939 & 354.603 & 353.250 \\
\hline & Total ESV & 4532.341 & 4439.352 & 4394.293 & 4293.343 \\
\hline
\end{tabular}
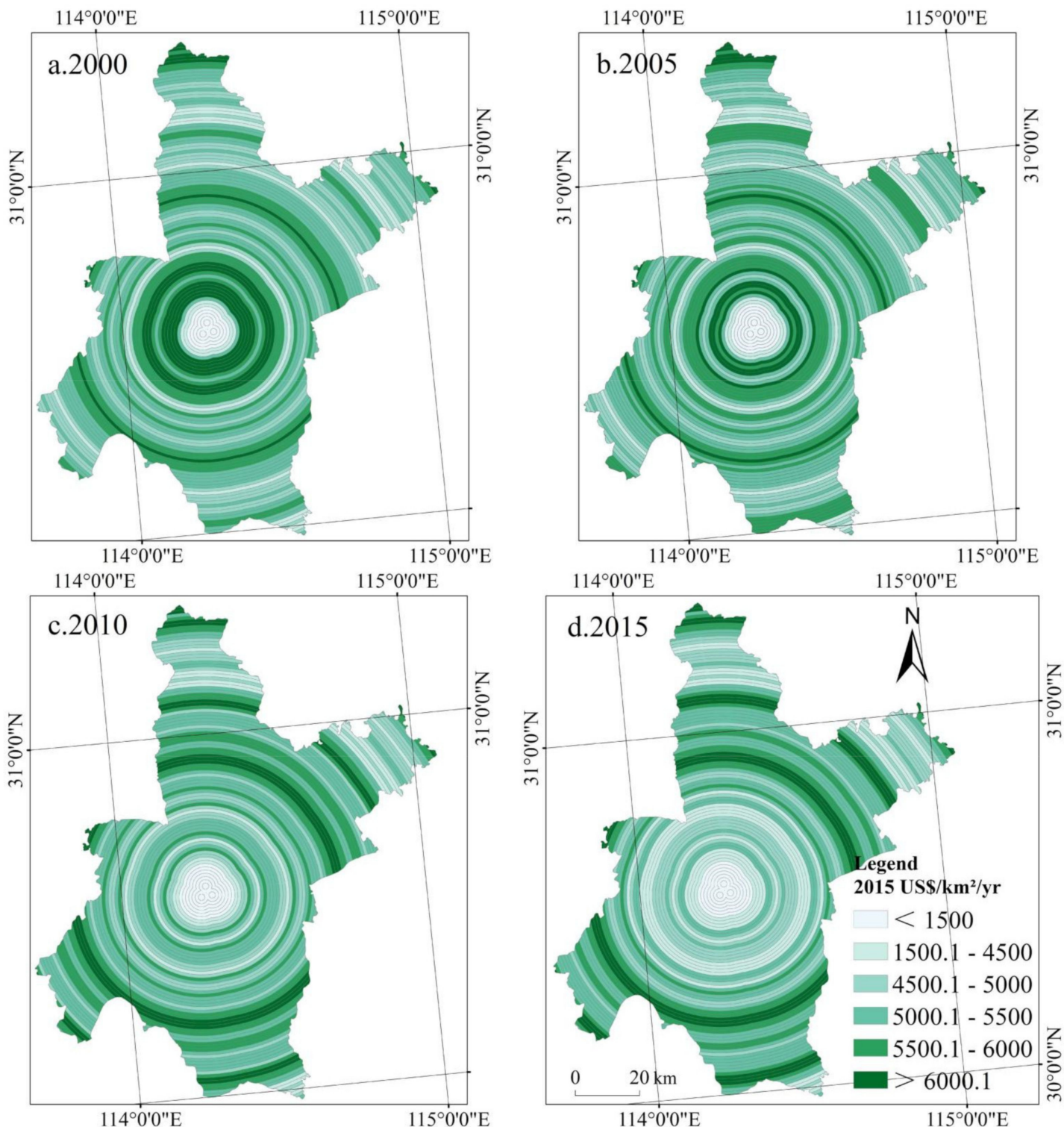

Figure 10. Spatial pattern of average ecosystem services value in Wuhan at the $1 \mathrm{~km}$ buffer scale from 2000 to 2015 (a-d), (a) is the patial pattern of average ecosystem services value in Wuhan at the $1 \mathrm{~km}$ buffer scale in 2000; (b) is the patial pattern of average ecosystem services value in Wuhan at the $1 \mathrm{~km}$ buffer scale in 2005; (c) is the patial pattern of average ecosystem services value in Wuhan at the $1 \mathrm{~km}$ buffer scale in 2010; (d) is the patial pattern of average ecosystem services value in Wuhan at the $1 \mathrm{~km}$ buffer scale in 2015. 

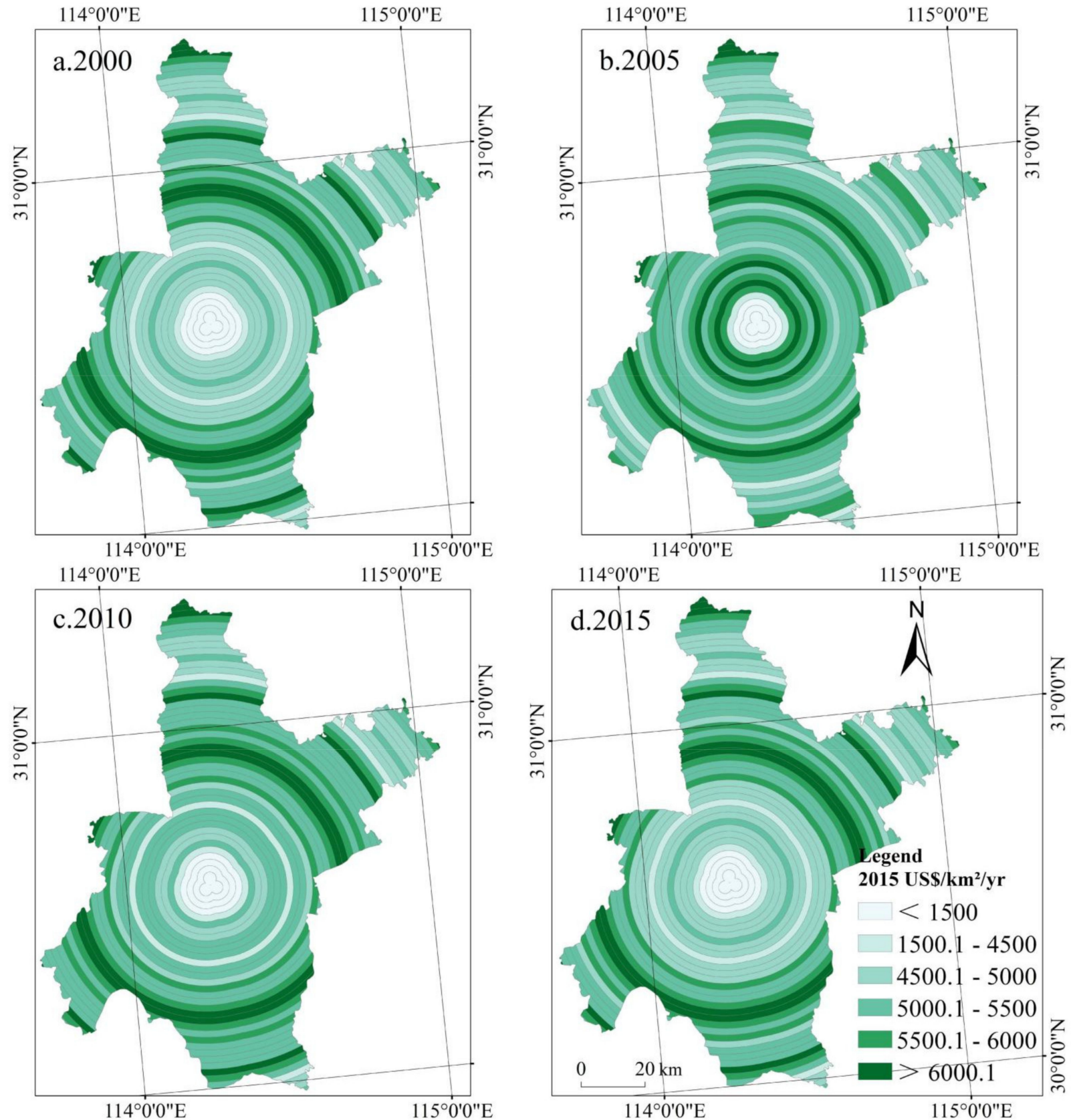

Figure 11. Spatial pattern of average ecosystem services value in Wuhan at the $2 \mathrm{~km}$ buffer scale from 2000 to 2015 (a-d), (a) is the patial pattern of average ecosystem services value in Wuhan at the $2 \mathrm{~km}$ buffer scale in 2000; (b) is the patial pattern of average ecosystem services value in Wuhan at the $2 \mathrm{~km}$ buffer scale in 2005; (c) is the patial pattern of average ecosystem services value in Wuhan at the $2 \mathrm{~km}$ buffer scale in 2010; (d) is the patial pattern of average ecosystem services value in Wuhan at the $2 \mathrm{~km}$ buffer scale in 2015. 

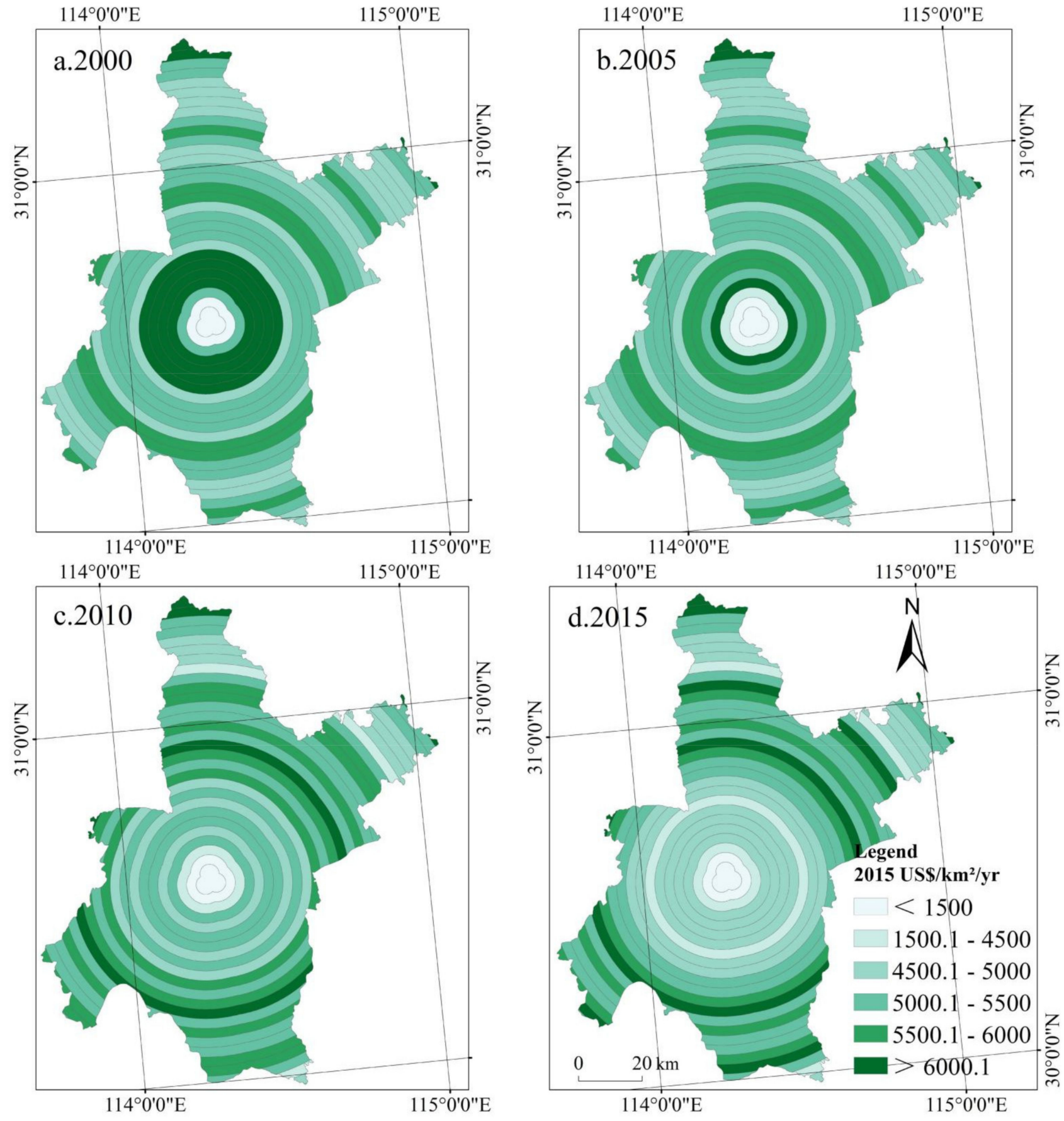

Figure 12. Spatial pattern of average ecosystem services value in Wuhan at the $3 \mathrm{~km}$ buffer scale from 2000 to 2015 (a-d). (a) is the patial pattern of average ecosystem services value in Wuhan at the $3 \mathrm{~km}$ buffer scale in 2000; (b) is the patial pattern of average ecosystem services value in Wuhan at the $3 \mathrm{~km}$ buffer scale in 2005; (c) is the patial pattern of average ecosystem services value in Wuhan at the $3 \mathrm{~km}$ buffer scale in 2010; (d) is the patial pattern of average ecosystem services value in Wuhan at the $3 \mathrm{~km}$ buffer scale in 2015.

\subsection{Econometrics Test Results in Wuhan from 2000 to 2015}

Mixed-, fixed-, and random-effects models were used to measure the impact of landscape pattern metrics on the average ESV at the 1, 2, and $3 \mathrm{~km}$ buffer-zone scales. The regression results of each of the buffer-zone scales are listed in Tables $4-6$, respectively. The $p$-value of the $\mathrm{F}$ test was significant at 0.0001 ; therefore, the null hypothesis was strongly rejected. The results demonstrate that the performance of the fixed-effects model was superior to that of the mixed regression model and that each individual factor should have 
its own intercept term. In addition, the Hausman test was used to determine whether random- or fixed-effects should be used in the models, and the results also rejected the null hypothesis. Therefore, a fixed-effects model should be adopted. Additionally, after comparing the individual and fixed-effects, time and fixed-effects, and individual and time fixed-effects models, the latter was determined to be the optimal model. Therefore, the individual and time fixed-effects model was used in this study to explain the influence mechanism of the landscape pattern index on average ESV.

Table 4. Estimation results of the non-spatial panel model at the $1 \mathrm{~km}$ buffer scale.

\begin{tabular}{|c|c|c|c|}
\hline Variable & Pooled OLS & $\begin{array}{l}\text { Individual and } \\
\text { Time-Period } \\
\text { Random Effects }\end{array}$ & $\begin{array}{c}\text { Individual and } \\
\text { Time-Period Fixed } \\
\text { Effects }\end{array}$ \\
\hline PD & $\begin{array}{c}-0.726^{* * *} \\
(0.194)\end{array}$ & $\begin{array}{l}-0.020 \\
(0.104)\end{array}$ & $\begin{array}{c}-0.726^{* * *} \\
(0.194)\end{array}$ \\
\hline LSI & $\begin{array}{l}1.676^{* *} \\
(0.488)\end{array}$ & $\begin{array}{c}0.308^{* * *} \\
(0.092)\end{array}$ & $\begin{array}{l}1.676^{* *} \\
(0.488)\end{array}$ \\
\hline AREA_AM & $\begin{array}{c}-0.382^{* *} \\
(0.141)\end{array}$ & $\begin{array}{c}-0.268^{* * *} \\
(0.058)\end{array}$ & $\begin{array}{c}-0.382 \text { ** } \\
(0.141)\end{array}$ \\
\hline FRAC_AM & $\begin{array}{l}3.471 * \\
(1.649)\end{array}$ & $\begin{array}{l}2.590 * * \\
(0.958)\end{array}$ & $\begin{array}{l}3.471 * \\
(1.649)\end{array}$ \\
\hline CONTAG & $\begin{array}{c}0.305 \\
(0.421)\end{array}$ & $\begin{array}{l}-1.404^{* * *} \\
(0.258)\end{array}$ & $\begin{array}{c}0.305 \\
(0.421)\end{array}$ \\
\hline IJI & $\begin{array}{l}-0.226 \\
(0.188)\end{array}$ & $\begin{array}{c}-0.772 * * * \\
(0.129)\end{array}$ & $\begin{array}{l}-0.226 \\
(0.188)\end{array}$ \\
\hline DIVISION & $\begin{array}{l}-1.688 \\
(0.986)\end{array}$ & $\begin{array}{c}-1.766^{* * *} \\
(0.149)\end{array}$ & $\begin{array}{l}-1.688 \\
(0.986)\end{array}$ \\
\hline SPLIT & $\begin{array}{l}-0.085 \\
(0.107)\end{array}$ & $\begin{array}{c}-0.182 * * \\
(0.066)\end{array}$ & $\begin{array}{l}-0.085 \\
(0.107)\end{array}$ \\
\hline SHDI & $\begin{array}{l}0.547^{* *} \\
(0.211)\end{array}$ & $\begin{array}{l}0.466^{* *} \\
(0.135)\end{array}$ & $\begin{array}{c}0.547 * * \\
(0.211)\end{array}$ \\
\hline$R$-squared & 0.802 & 0.760 & 0.509 \\
\hline Constant & $\begin{array}{l}-2.303 \\
(1.882)\end{array}$ & $\begin{array}{c}0.878 \\
(1.024)\end{array}$ & $\begin{array}{l}-2.303 \\
(1.882)\end{array}$ \\
\hline$N$ & 352 & 352 & 352 \\
\hline $\begin{array}{l}\text { Fixed effects VS } \\
\text { random effects }\end{array}$ & Hausmann test & $\begin{array}{c}\text { chi2 }(10)=(b-B)^{\prime}\left[\left(V_{-} b_{-}-\right.\right. \\
\left.\text {V_B })^{\wedge}(-1)\right](b-B) \\
=72.83\end{array}$ & Prob $>$ chi $2=0.000$ \\
\hline $\begin{array}{c}\text { Fixed effects VS } \\
\text { mixed effects }\end{array}$ & $F$ test & $F=14.40$ & $p=0.000$ \\
\hline
\end{tabular}

Notes: ${ }^{* *} p \leq 0.001,{ }^{* *} p \leq 0.01$, and ${ }^{*} p \leq 0.05$. The standard deviations are in parentheses.

Table 5. Estimation results of the non-spatial panel model at the $2 \mathrm{~km}$ buffer scale.

\begin{tabular}{cccc}
\hline Variable & Pooled OLS & $\begin{array}{c}\text { Individual and } \\
\text { Time-Period } \\
\text { Random Effects }\end{array}$ & $\begin{array}{c}\text { Individual and } \\
\text { Time-Period Fixed } \\
\text { Effects }\end{array}$ \\
\hline PD & 0.100 & -0.167 & $-0.609^{*}$ \\
LSI & $(0.126)$ & $(0.128)$ & $(0.243)$ \\
AREA_AM & $0.454^{* * *}$ & 0.243 & 1.163 \\
FRAC_AM & $(0.137)$ & $(0.139)$ & $(0.772)$ \\
CONTAG & -0.096 & $-0.259^{*}$ & -0.571 \\
& $(0.209)$ & $(0.100)$ & $(0.415)$ \\
IJI & -3.356 & 1.808 & 2.960 \\
& $(1.682)$ & $(1.428)$ & 0.361 \\
& $-2.725^{* * *}$ & $-1.606^{* * *}$ & $(0.734)$ \\
& $(0.679)$ & $(0.418)$ & -0.432 \\
& $-1.239^{* *}$ & $-1.127^{* * *}$ & $(0.349)$ \\
\hline
\end{tabular}


Table 5. Cont.

\begin{tabular}{|c|c|c|c|}
\hline Variable & Pooled OLS & $\begin{array}{l}\text { Individual and } \\
\text { Time-Period } \\
\text { Random Effects }\end{array}$ & $\begin{array}{c}\text { Individual and } \\
\text { Time-Period Fixed } \\
\text { Effects }\end{array}$ \\
\hline DIVISION & $\begin{array}{c}-1.831^{* * *} \\
(0.392)\end{array}$ & $\begin{array}{l}-2.287^{* * *} \\
(0.293)\end{array}$ & $\begin{array}{l}-2.823 \\
(1.990)\end{array}$ \\
\hline SPLIT & $\begin{array}{l}-0.263 \\
(0.145)\end{array}$ & $\begin{array}{l}-0.088 \\
(0.120)\end{array}$ & $\begin{array}{l}-0.023 \\
(0.210)\end{array}$ \\
\hline SHDI & $\begin{array}{c}0.461 \\
(0.275)\end{array}$ & $\begin{array}{l}0.852 * * \\
(0.257)\end{array}$ & $\begin{array}{l}1.290^{* * *} \\
(0.478)\end{array}$ \\
\hline R-squared & 0.741 & 0.689 & 0.399 \\
\hline Constant & $\begin{array}{l}8.002 * * * \\
(2.008)\end{array}$ & $\begin{array}{c}2.484 \\
(1.512)\end{array}$ & $\begin{array}{l}-0.824 \\
(2.618)\end{array}$ \\
\hline$N$ & 176 & 176 & 176 \\
\hline $\begin{array}{l}\text { Fixed effects VS } \\
\text { random effects }\end{array}$ & Hausmann test & $\begin{array}{c}\text { chi2 }(10)=(b-B)^{\prime}\left[\left(V_{-} b-\right.\right. \\
\left.\text { V_B })^{\wedge}(-1)\right](b-B) \\
=27.30\end{array}$ & Prob $>$ chi $2=0.002$ \\
\hline $\begin{array}{l}\text { Fixed effects VS } \\
\text { mixed effects }\end{array}$ & $F$ test & $F=13.17$ & $p=0.000$ \\
\hline
\end{tabular}

Notes: ${ }^{* * *} p \leq 0.001,{ }^{* *} p \leq 0.01$, and ${ }^{*} p \leq 0.05$. The standard deviations are in parentheses.

Table 6. Estimation results of the non-spatial panel model at the $3 \mathrm{~km}$ buffer scale.

\begin{tabular}{|c|c|c|c|}
\hline Variable & Pooled OLS & $\begin{array}{l}\text { Individual and } \\
\text { Time-Period } \\
\text { Random Effects }\end{array}$ & $\begin{array}{c}\text { Individual and } \\
\text { Time-Period Fixed } \\
\text { Effects }\end{array}$ \\
\hline PD & $\begin{array}{l}0.320^{*} \\
(0.152)\end{array}$ & $\begin{array}{l}-0.083 \\
(0.178)\end{array}$ & $\begin{array}{l}-0.825^{* *} \\
(0.262)\end{array}$ \\
\hline LSI & $\begin{array}{l}0.312^{* *} \\
(0.103)\end{array}$ & $\begin{array}{l}0.543^{* * *} \\
(0.144)\end{array}$ & $\begin{array}{l}2.525^{* *} \\
(0.707)\end{array}$ \\
\hline AREA_AM & $\begin{array}{c}0.088 \\
(0.171)\end{array}$ & $\begin{array}{c}-0.436^{* * *} \\
(0.118)\end{array}$ & $\begin{array}{l}-0.764^{* *} \\
(0.237)\end{array}$ \\
\hline FRAC_AM & $\begin{array}{l}-4.637^{* *} \\
(1.459)\end{array}$ & $\begin{array}{l}-0.460 \\
(1.505)\end{array}$ & $\begin{array}{c}0.434 \\
(2.045)\end{array}$ \\
\hline CONTAG & $\begin{array}{c}-3.961^{* * *} \\
(0.544)\end{array}$ & $\begin{array}{l}-1.858^{* * *} \\
(0.454)\end{array}$ & $\begin{array}{l}1.483 * \\
(0.654)\end{array}$ \\
\hline IJI & $\begin{array}{c}-1.203^{* * *} \\
(0.271)\end{array}$ & $\begin{array}{l}-0.903^{* *} \\
(0.282)\end{array}$ & $\begin{array}{l}-0.027 \\
(0.368)\end{array}$ \\
\hline DIVISION & $\begin{array}{c}0.505 \\
(0.765)\end{array}$ & $\begin{array}{l}-1.748^{* *} \\
(0.659)\end{array}$ & $\begin{array}{l}-3.380 * \\
(1.469)\end{array}$ \\
\hline SPLIT & $\begin{array}{l}-0.218^{*} \\
(0.098)\end{array}$ & $\begin{array}{l}-0.381^{* *} \\
(0.116)\end{array}$ & $\begin{array}{l}-0.513^{* *} \\
(0.149)\end{array}$ \\
\hline SHDI & $\begin{array}{l}-0.564 \\
(0.358)\end{array}$ & $\begin{array}{c}0.301 \\
(0.322)\end{array}$ & $\begin{array}{l}0.897 * * \\
(0.375)\end{array}$ \\
\hline R-squared & 0.848 & 0.782 & 0.668 \\
\hline Constant & $\begin{array}{l}8.793 * * * \\
(1.516)\end{array}$ & $\begin{array}{l}4.532 * * * \\
(1.523)\end{array}$ & $\begin{array}{l}0.703 \\
1.963\end{array}$ \\
\hline$N$ & 120 & 120 & 120 \\
\hline $\begin{array}{l}\text { Fixed effects VS } \\
\text { random effects }\end{array}$ & Hausmann test & $\begin{array}{c}\text { chi2 } 2(10)=(b-B)^{\prime}\left[\left(V_{-} b-\right.\right. \\
\left.\text { V_B })^{\wedge}(-1)\right](b-B) \\
=54.87\end{array}$ & Prob $>$ chi $2=0.000$ \\
\hline $\begin{array}{c}\text { Fixed effects VS } \\
\text { mixed effects }\end{array}$ & $F$ test & $F=13.27$ & $p=0.000$ \\
\hline
\end{tabular}

Notes: ${ }^{* * *} p \leq 0.001,{ }^{* *} p \leq 0.01$, and ${ }^{*} p \leq 0.05$. The standard deviations are in parentheses.

The regression results demonstrated that the landscape pattern metrics exerted significant impacts on average ESV. Specifically, the regression coefficients of LSI, FRAC_AM, CONTAG, and SHDI at these three buffer-zone scales were all positive, indicating that an increase in these landscape pattern metrics increased the average ESV; however, not all regression coefficients were significant. The LSI, FRAC_AM, and SHDI regression 
coefficients were all significant at the $1 \mathrm{~km}$ buffer scale, whereas CONTAG was not. Only SHDI was significant at the $2 \mathrm{~km}$ scale, and LSI, FRAC_AM, CONTAG, and SHDI were significant at a buffer scale of $3 \mathrm{~km}$. The regression coefficients of PD, AREA_AM, IJI, DIVISION, and SPLIT were all negative; however, they were not all significant. Specifically, PD and AREA_AM were significant at the $1 \mathrm{~km}$ buffer scale, and PD was the only landscape pattern metric that was significant at the $2 \mathrm{~km}$ buffer scale. At the $3 \mathrm{~km}$ buffer scale, PD, AREA_AM, DIVISION, and SPLIT were significant. Based on this analysis, the impacts of landscape patterns on the average ESVs at different scales varied significantly.

\section{Discussion}

\subsection{Buffer characteristics of Landscape Pattern Index and ESV}

During the study period, cultivated land in Wuhan was the primary land-use type $(>50 \%)$, which exhibited a continuously decreasing trend, followed by water area $(>18 \%)$, which exhibited a continuously increasing trend. The proportion of construction land also continued to increase. Substantial differences existed in the landscape pattern metrics [90]. For example, the PD, LSI, DIVISION, SPLIT, and SHDI in Wuhan gradually increased during the study period, whereas AREA_AM, FRAC_AM, and CONTAG gradually decreased. The IJI index increased in volatility during the study period. In addition, the fragmentation of the Wuhan landscape gradually increased, and the fragmentation degree was the highest for construction land. Along the gradient of the central urban area to the fringe area, the Wuhan landscape patterns exhibited a significant buffer-zone structure. PD, LSI, DIVISION, IJI, SPLIT, and SHDI exhibited similar features in space. The core area of buffers was low and, with the expansion of the buffer zone, these landscape pattern metrics increased and then significantly decreased. AREA_AM, FRAC_AM, and CONTAG experienced similar spatial changes in higher core areas. They gradually decreased with an increase in the buffer zone, followed by an increasing and then decreasing trend.

The ESV provision capacity in Wuhan exhibited a significant downward trend from $5,289.073 \mathrm{USD} / \mathrm{hm}^{2}$ in 2000 to $5,010.089 \mathrm{USD} / \mathrm{hm}^{2}$ in 2015. This finding is consistent with that of Wang et al. [91]. The water area provided the greatest proportion of ESV $(>50 \%)$ and showed an increasing trend during the period studied. The average ESV in the core area of Wuhan was low, and the buffer zone containing a low average ESV expanded outward from 2000 to 2015. Under the influence of the vast water area in Wuhan, the average ESV from the core area to the fringe area fluctuated. The ESV in the core area declined rapidly, especially within the $22 \mathrm{~km}$ buffer zone at 1,2, and $3 \mathrm{~km}$ buffer-zone scales from 2000 to 2010 (Figure 13). The rapid expansion of construction land in these areas has resulted in the decrease of ecosystem services. Forestland and cultivated land were the dominant landscapes in the fringe area of Wuhan during the period studied; the average ESV in these buffer zones was obviously higher [19]. Specifically, the average ESV in the buffer zones beyond $22 \mathrm{~km}$ did not fluctuate significantly during 2000-2005. A significant increase in the average ESV was found in the buffer zones between 22 and $60 \mathrm{~km}$, followed by an evident decrease in the ESV of the buffer zones beyond $60 \mathrm{~km}$. During 2010-2015, the fluctuations in average ESV changes were not obvious, but the average ESV in the buffer zones within $22 \mathrm{~km}$ still exhibited a significant decrease. In addition, the buffer zone with the greatest reduction in average ESV moved to the outer buffer zone of Wuhan city. 

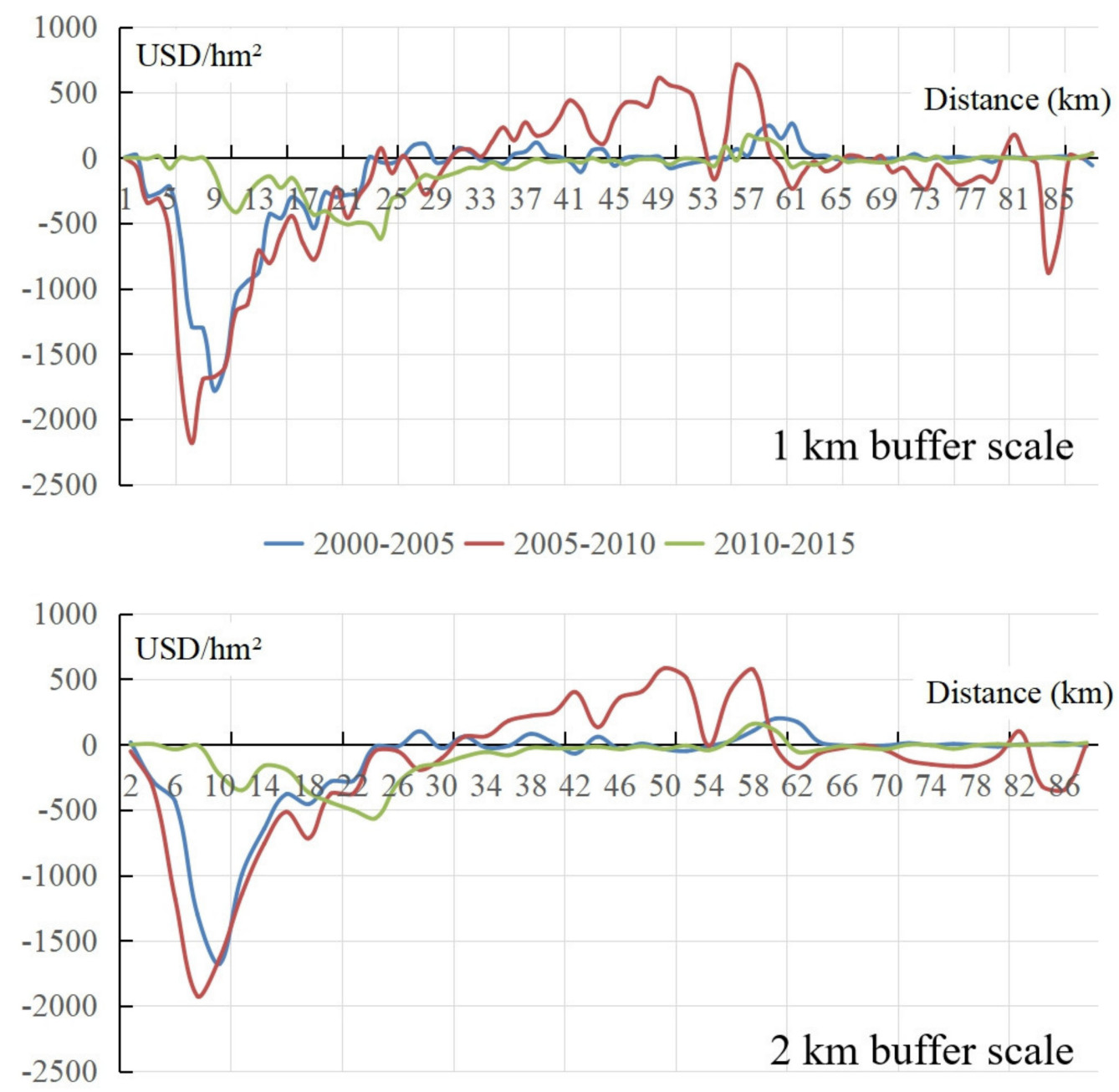

$-2000-2005-2005-2010-2010-2015$

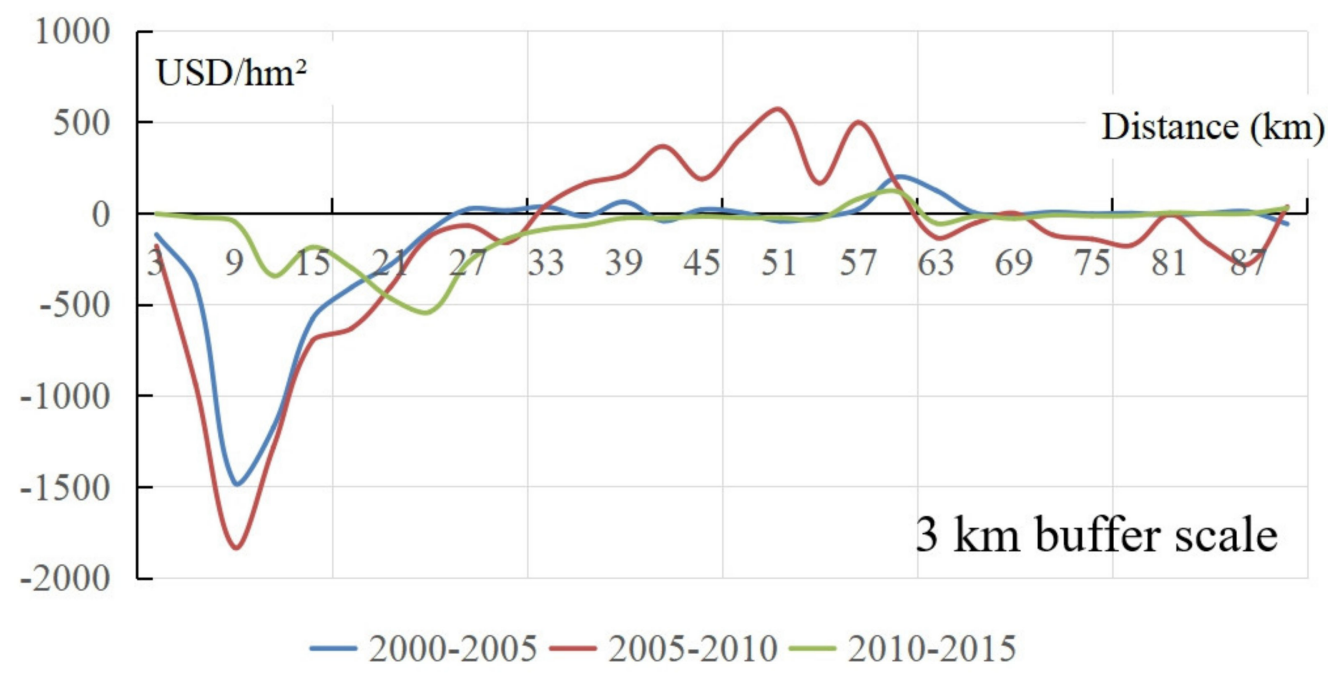

Figure 13. Average ecosystem services value changes in Wuhan at 1, 2, and $3 \mathrm{~km}$ buffer scales.

Wuhan expanded orbitally and now has six ring roads, the first of which has a total length of $28 \mathrm{~km}$ and was completed in 1995; the second is $48 \mathrm{~km}$ in length and was completed in 2015. The third ring road, which is a ring expressway within Wuhan, is $91 \mathrm{~km}$ in length, and it was opened to traffic in 2010. The fourth ring road, a ring highway in Wuhan, is approximately $143 \mathrm{~km}$ long, and it was opened to traffic in 2020 . The fifth ring 
road, called the "Wuhan Belt Highway" or "Wuhan Outer Ring Road," is $191 \mathrm{~km}$ long, and it was opened to traffic in 2007. The Dongxihu, Huangpi, Xinzhou, Hongshan, Jiangxia, and Caidian districts are connected by the fifth ring road. The sixth ring road, which is also called the "Wuhan Circle Belt Highway," is approximately $560 \mathrm{~km}$ long. The aim of the sixth ring road was to build a " $1 \mathrm{~h}$ traffic circle" in Wuhan and a " $2 \mathrm{~h}$ traffic circle" in the surrounding influential cities to promote Wuhan circle traffic integration. Previous studies have illustrated that roads are important factors in construction land expansion; thus, the construction of these loop lines promotes landscape heterogeneity in Wuhan. In addition, changes in the land-use landscape pattern significantly impact ecosystem services supply capacities at different buffer-zone scales.

\subsection{Impacts of Landscape Pattern on ESV}

The regression results demonstrated that the LSI, FRAC_AM, CONTAG, and SHDI regression coefficients at the studied buffer-zone scales were all positive, indicating that an increase in these landscape pattern metrics promotes ESV improvement. Specifically, the increase in LSI indicated that the irregularity of the landscape pattern index in Wuhan increased during the study period, which contributed to the increase in the average ESV. Similar results were reported by Yushanjiang et al. [37]. However, Liu et al. [16] found that the LSI was negatively associated with the average ESV. FRAC_AM also reflected the impact of human activities on the landscape pattern. Natural landscapes that are less disturbed by human activities typically exhibit a high average fractal dimension index, whereas artificial landscapes greatly affected by human activities tend to exhibit a low fractal dimension value. Therefore, an increase in the FRAC_AM index indicates an increase in ecosystem services. This result is in agreement with those of Yushanjiang et al. [37] and Zhang et al. [14]. The CONTAG index indicated whether the dominant patch type in the landscape formed sufficient connectivity; otherwise, it indicated that the landscape was a dense pattern with multiple elements, and the fragmentation degree of the landscape was high. High landscape connectivity can lead to an increase in ecosystem services. Yushanjiang et al. [37] and Hou et al. [42] found that the CONTAG index was negatively correlated with ecosystem services. The increase in SHDI indicates that an increase in landscape diversity richness can also lead to a rise in ecosystem services. Yushanjiang et al. [37] found the same result, while Liu et al. [16] demonstrated that the SHDI was negatively associated with supplying and supporting services and positively associated with regulating and cultural services.

The PD, AREA_AM, IJI, DIVISION, and SPLIT regression coefficients were all negative, indicating that landscape fragmentation and a high degree of patch-type alteration lead to a decline in ecosystem services. Changes in the landscape pattern lead to changes in the components, structure, functions, and biochemistry of regional ecosystems, ultimately leading to a change in ESV. However, the impacts of the landscape index on ecosystem services varied greatly across different scales and research areas. For example, Yushanjiang et al. [37] found that an increase in PD leads to an increase in ecosystem services, while Hou et al. [50] and Liu et al. [16] contended that an increase in PD leads to a decrease in ecosystem services. According to Liu et al. [16] and Zhao et al. [15], AREA_AM was positively associated with ecosystem services. Similarly, IJI in Zhao et al. [15] and Liu et al. [16] was found to be negatively correlated with ecosystem services, whereas Zhang et al. [14] and Yushanjiang et al. [37] found that IJI was positively correlated with ecosystem services and food production, respectively. Liu et al. [16], Yushanjiang et al. [37], and Hou et al. [50] found DIVISION to be positively associated with ecosystem services, while Yushanjiang et al. [37] also demonstrated SPLIT to be positively correlated with ecosystem services.

Improved production and living standards and diverse needs drive humans to gradually increase the development and utilization of ecosystem services. The resulting changes in landscape patterns have damaged the original components and structures of ecosystems, severely affected ecosystem functions, and reduced the value of ecosystem services. The 
impact of the evolution of landscape patterns on ecosystem services is a complex process, and further scientific evaluation indicators should be selected for assessment. Further exploration of the correlations and mechanisms between landscape patterns and ecosystem services at different scales should be considered in future studies.

\subsection{Policy Implications}

Understanding the influence mechanism between landscape patterns and ESV can provide a scientific reference for ecosystem conservation. The findings of this study demonstrate that the relationship between landscape pattern and ecosystem services is extremely complex, with trade-offs and synergies. On the one hand, the spatial heterogeneity of the landscape pattern leads to ESV spatial heterogeneity, and the multifunctionality of the landscape is closely related to the diversity and stability of ecosystem services $[4,72]$. On the other hand, the quality of ecosystem services not only affects land-use quantity and structure but also affects land-use patterns, scales, and layouts, in addition to human socioeconomic behaviors [79]. Land development projects can optimize land-use and improve ecosystem services. For example, the ecologicalization of roads and canals can reduce species migration resistance and improve energy, material, and information flows within an ecosystem. Land-use consolidation projects, such as returning cultivated land to forestland, cultivated land consolidation, construction land consolidation, and optimization, can promote supplying and regulating services, including boosting land-use efficiency, labor productivity, quality of life, and the environment [92-96]. Therefore, the landscape patterns of ecological and construction land should be optimized in land-use planning, and ecological land should be protected. In addition, during urbanization, the spatial form of urban areas should be controlled, and scattered construction land expansion with low efficiency should be avoided where possible to minimize its impact on ecosystem services [96].

The provision of ecosystem services is closely related to human needs, which can reflect the value of ecosystem services. The interaction mechanism between landscape patterns and ecosystem services can be analyzed to reflect the interactions between landscape patterns and ecological processes. Within certain spatiotemporal intervals, changes in landscape patterns are manifested as changes in the type, size, and spatial location of various land-use types. These changes affect landscape structures and ecosystem spatial distributions, leading to changes in landscape material, energy, and ecological flows and, ultimately, the supply and maintenance of ecosystem services. Describing the geometric features of a landscape pattern without considering the related ecological processes is insufficient for exploring the ecological effects of landscape changes [50]. Ecosystem services link the ecosystem to the social system. Studying the impact of landscape patterns on ecosystem services can help deepen our understanding of their interaction mechanisms and provide scientific references and technical solutions for the sustainable development of socioeconomic systems and ecosystems.

\subsection{Limitations and Future Directions}

By measuring the landscape pattern metrics and the spatiotemporal distribution characteristics of ESV at 1, 2, and $3 \mathrm{~km}$ buffer-zone scales in Wuhan, this study used a non-spatial panel model to evaluate the impact of landscape pattern metrics on ecosystem services. Scale and pattern are core issues in landscape ecology and geography $[97,98]$. Previous studies have explored the impact of landscape patterns on ecosystem services at multiple scales $[14,16,37,99]$. However, research on the interaction mechanism between landscape patterns and ecosystem services requires the study of the impact of scale effects on ecological processes and mechanisms. Selecting a scale that is too large often leads to relevant details being ignored, whereas selecting a scale that is too small can neglect an overall rule. Therefore, selecting an appropriate scale is of extreme importance for landscape pattern and ecosystem services research [36]. The impacts of different or continuous spatial scales on the relationship between landscape pattern metrics and ecosystem 
services should be further studied. This study also adopted the non-spatial panel model to measure the impact of landscape patterns on ecosystem services without considering spatial spillover effects; in future studies, dynamic spatial panel analysis can be used to explore their mechanisms. This study quantified the impact of landscape patterns on ecosystem services; however, it did not reveal the relationships between landscape patterns, ecological processes, and ecosystem services. Thus, this study ignored the internal mechanism and response degree of each landscape pattern index impact on ecosystem services. Therefore, in future studies, it is necessary to acquire field test data and to select additional scientific evaluation indicators and methods to reveal the relationships between landscape patterns and ecosystem services and to clarify the influence mechanisms and scale effects that landscape patterns have on ecosystem services. In addition, although this study measured the impact of a landscape pattern index on ecosystem services through a non-spatial panel model, it lacks a comprehensive consideration of other factors impacting ecosystem services. Further consideration should be given to the impact of additional factors on ecosystem services in future studies.

\section{Conclusions}

Based on land-use/cover change data with a $30 \mathrm{~m}$ resolution from 2000, 2005, 2010, and 2015, landscape pattern metrics and ESVs at buffer-zone scales of 1,2, and $3 \mathrm{~km}$ were measured for Wuhan, China. Then, a set of non-spatial panel models were used to determine the impact mechanism of the landscape pattern on ecosystem services. The main findings were as follows:

(1) We demonstrated that rapid urbanization in Wuhan has led to significant changes in landscape patterns; PD, LSI, DIVISION, SPLIT, and SHDI exhibited significant increasing trends, whereas AREA_AM, FRAC_AM, and CONTAG exhibited significant decreasing trends. The landscape pattern metrics also exhibited significant spatial heterogeneity.

(2) In 2000, 2005, 2010, and 2015, the ESVs provided by ecosystems in Wuhan were USD 4,532.341, 4,439.352, 4,394.293, and 4,293.343 million, respectively, indicating that the Wuhan ESV capacity declined. Among the subcategory ecosystem service proportions, hydrological regulations and waste treatment were higher, accounting for $24 \%$ of the ESV, whereas the raw material production function was the lowest, accounting for approximately $3.5 \%$. The average ESVs in the core area of Wuhan were low, and buffer layers with low average ESVs expanded over time.

(3) Individual and time fixed-effects models were determined to be the optimal types of model. The landscape pattern metrics significantly impacted the ecosystem services; however, these impacts varied substantially. PD, AREA_AM, IJI, DIVISION, and SPLIT were found to be negatively associated with average ESV, while LSI, FRAC_AM, CONTAG, and SHDI were positively associated with average ESV. The significance level was different at different buffer-zone scales. The results of this study can provide important implications for the formulation of ecosystem protection and landscape planning policies.

Author Contributions: Conceptualization, W.C. and J.Z.; methodology, W.C.; software, W.C.; validation, W.C., J.Z. and Y.C.; formal analysis, W.C.; investigation, W.C.; resources, W.C.; data curation, J.Z.; writing—original draft preparation, W.C.; writing—review and editing, Y.C. and J.L.; visualization, J.Z.; supervision, J.Z. and J.L.; project administration, W.C.; funding acquisition, W.C. All authors have read and agreed to the published version of the manuscript.

Funding: This research was funded by the Natural Science Foundation of China, grant number 42001187, 42001231, and 41701629. The project was also supported by State Key Laboratory of Earth Surface Processes and Resource Ecology (2021-KF-03).

Data Availability Statement: The data that support the findings of this study are available from the corresponding author upon reasonable request. 
Conflicts of Interest: The authors declare no conflict of interest.

\section{References}

1. Bai, L.M.; Xiu, C.L.; Feng, X.H.; Liu, D.Q. Influence of urbanization on regional habitat quality: A case study of Changchun City. Habitat Int. 2019, 93, 102042. [CrossRef]

2. Dadashpoor, H.; Azizi, P.; Moghadasi, M. Land use change, urbanization, and change in landscape pattern in a metropolitan area. Sci. Total Environ. 2019, 655, 707-719. [CrossRef] [PubMed]

3. Deng, J.S.; Wang, K.; Hong, Y.; Qi, J.G. Spatio-temporal dynamics and evolution of land use change and landscape pattern in response to rapid urbanization. Landsc. Urban Plan. 2009, 92, 187-198. [CrossRef]

4. Duarte, G.T.; Santos, P.M.; Cornelissen, T.G.; Ribeiro, M.C.; Paglia, A.P. The effects of landscape patterns on ecosystem services: Meta-analyses of landscape services. Landsc. Ecol. 2018, 33, 1247-1257. [CrossRef]

5. Estoque, R.C.; Murayama, Y. Landscape pattern and ecosystem service value changes: Implications for environmental sustainability planning for the rapidly urbanizing summer capital of the Philippines. Landsc. Urban Plan. 2013, 116, 60-72. [CrossRef]

6. Jiao, L.M.; Xiao, F.T.; Xu, G.; Lu, Y.N. Spatial-temporal response of green land fragmentation patterns to urban expansion in Wuhan metropolitan area. Res. Sci. 2015, 37, 1650-1660.

7. Jiao, L.M. Urban land density function: A new method to characterize urban expansion. Landsc. Urban Plan. 2015, 139, 26-39. [CrossRef]

8. Zhao, R.; Jiao, L.M.; Xu, G.; Xu, Z.B.; Dong, T. The relationship between urban spatial growth and population density change Acta Geogr. Sin. 2020, 75, 695-707.

9. Taubenböck, H.; Wegmann, M.; Roth, A.; Mehl, H.; Dech, S. Urbanization in India-Spatiotemporal analysis using remote sensing data. Comput. Environ. Urban Syst. 2009, 33, 179-188. [CrossRef]

10. Schneider, A.; Woodcock, C.E. Compact, dispersed, fragmented, extensive? A comparison of urban growth in twenty-five global cities using remotely senseddata, pattern metrics and census information. Urban Stud. 2008, 45, 659-692. [CrossRef]

11. Seto, K.C.; Guneralp, B.; Hutyra, L.R. Global forecasts of urban expansion to 2030 and direct impacts on biodiversity and carbon pools. Proc. Natl. Acad. Sci. USA 2012, 109, 16083-16088. [CrossRef]

12. Seto, K.C.; Fragkias, M. Quantifying spatiotemporal patterns of urban land-use change in four cities of China with time series landscape metrics. Landsc. Ecol. 2005, 20, 871-888. [CrossRef]

13. Hao, R.F.; Yu, D.Y.; Liu, Y.P.; Liu, Y.; Qiao, J.M.; Wang, X.; Du, J.S. Impacts of changes in climate and landscape pattern on ecosystem services. Sci. Total Environ. 2017, 579, 718-728. [CrossRef] [PubMed]

14. Zhang, J.; Qu, M.; Wang, C.; Zhao, J.; Cao, Y. Quantifying landscape pattern and ecosystem service value changes: A case study at the county level in the Chinese Loess Plateau. Glob. Ecol. Conserv. 2020, 23, e1110. [CrossRef]

15. Zhao, Q.J.; Wen, Z.M.; Chen, S.L.; Ding, S.; Zhang, M.X. Quantifying land use/land cover and landscape pattern changes and impacts on ecosystem services. Int. J. Environ. Res. Public Health 2020, 17, 126. [CrossRef] [PubMed]

16. Liu, L.W.; Chen, X.R.; Chen, W.X.; Ye, X.Y. Identifying the impact of landscape pattern on ecosystem services in the Middle Reaches of the Yangtze River Urban Agglomerations, China. Int. J. Environ. Res. Public Health 2020, 17, 5063. [CrossRef] [PubMed]

17. Meentemeyer, V. Geographical perspectives of space, time, and scale. Landsc. Ecol. 1989, 3, 163-173. [CrossRef]

18. Ou, W.X.; Wang, H.N.; Tao, N. A land cover-based assessment of ecosystem services supply and demand dynamics in the Yangtze River Delta region. Acta Ecol. Sin. 2018, 38, 6337-6347.

19. Jiao, L.M.; Li, Z.H.; Xu, G.; Zhang, B.E.; Dong, T.; Gu, Y.Y. The characteristics and patterns of spatially aggregated elements in urban areas of Wuhan. Acta Geogr. Sin. 2017, 72, 1432-1443.

20. Dai, E.F.; Wang, Y.H.; Ma, L.; Yin, L.; Wu, Z. “Urban-rural” gradient analysis of landscape changes around cities in mountainous regions: A case study of the Hengduan mountain region in Southwest China. Sustainability 2018, 10, 1019. [CrossRef]

21. Vizzari, M.; Sigura, M. Landscape sequences along the urban-rural-natural gradient: A novel geospatial approach for identification and analysis. Landsc. Urban Plan. 2015, 140, 42-55. [CrossRef]

22. Luck, M.; Wu, J.G. A gradient analysis of urban landscape pattern: A case study from the Phoenix metropolitan region, Arizona, USA. Landsc. Ecol. 2002, 17, 327-339. [CrossRef]

23. Xu, Q.; Yang, R.; Zhuang, D.C.; Lu, Z.L. Spatial gradient differences of ecosystem services supply and demand in the Pearl River Delta region. J. Clean. Prod. 2021, 279, 123849. [CrossRef]

24. Kroll, F.; Müller, F.; Haase, D.; Fohrer, N. Rural-urban gradient analysis of ecosystem services supply and demand dynamics. Land Use Policy 2012, 29, 521-535. [CrossRef]

25. Mcdonnell, M.J.; Pickett, S.T.A.; Groffman, P.; Bohlen, P.; Pouyat, R.V.; Zipperer, W.C.; Parmelee, R.W.; Carreiro, M.M.; Medley, K. Ecosystem processes along an urban-to-rural gradient. Urban Ecosyst. 1997, 1, 21-36. [CrossRef]

26. Ma, S.; Qiao, Y.P.; Wang, L.J.; Zhang, J.C. Terrain gradient variations in ecosystem services of different vegetation types in mountainous regions: Vegetation resource conservation and sustainable development. For. Ecol. Manag. 2021, 482 , 118856. [CrossRef]

27. Santos-Martín, F.; Zorrilla-Miras, P.; Palomo, I.; Montes, C.; Benayas, J.; Maes, J. Protecting nature is necessary but not sufficient for conserving ecosystem services: A comprehensive assessment along a gradient of land-use intensity in Spain. Ecosyst. Serv. 2019, 35, 43-51. [CrossRef] 
28. Balzan, M.V.; Caruana, J.; Zammit, A. Assessing the capacity and flow of ecosystem services in multifunctional landscapes: Evidence of a rural-urban gradient in a Mediterranean small island state. Land Use Policy 2018, 75, 711-725. [CrossRef]

29. Baro, F.; Gomez-Baggethun, E.; Haase, D. Ecosystem service bundles along the urban-rural gradient: Insights for landscape planning and management. Ecosyst. Serv. 2017, 24, 147-159. [CrossRef]

30. Dai, E.F.; Wu, Z.; Du, X.D. A gradient analysis on urban sprawl and urban landscape pattern between 1985 and 2000 in the Pearl River Delta, China. Front. Earth Sci. 2018, 12, 791-807. [CrossRef]

31. Zhang, Z.X.; Li, N.; Wang, X.; Liu, F.; Yang, L.P. A comparative study of urban expansion in Beijing, Tianjin and Tangshan from the 1970s to 2013. Remote Sens. 2016, 8, 496. [CrossRef]

32. Sun, J.; Xia, H.P.; Lan, C.Y.; Xin, K. A gradient analysis based on the buffer zones of urban landscape pattern of the constructed area in Guigang City, Guangxi, China. Acta Ecol. Sin. 2006, 26, 655-662. [CrossRef]

33. Burgess, E.W. The growth of the city: An introduction to a research project. In Urban Ecology; Marzluff, J.M., Shulenberger, E., Endlicher, W., Alberti, M., Bradley, G., Ryan, C., Simon, U., ZumBrunnen, C., Eds.; Springer: Boston, MA, USA, 2008; pp. 71-78.

34. Dong, T.; Jiao, L.M.; Xu, G.; Yang, L.Y.; Liu, J.F. Towards sustainability? Analyzing changing urban form patterns in the United States, Europe, and China. Sci. Total Environ. 2019, 671, 632-643. [CrossRef]

35. Li, X.W.; Fang, J.Y.; Po, S.L. The comparison of spatial characteristics in urban landuse growth among the central and sub-cities in Shanghai Region. Geogr. Res. 2003, 22, 769-779.

36. Su, S.; Xiao, R.; Zhang, Y. Multi-scale analysis of spatially varying relationships between agricultural landscape patterns and urbanization using geographically weighted regression. Appl. Geogr. 2012, 32, 360-375. [CrossRef]

37. Yushanjiang, A.; Zhang, F.; Yu, H.; Kung, H. Quantifying the spatial correlations between landscape pattern and ecosystem service value: A case study in Ebinur Lake Basin, Xinjiang, China. Ecol. Eng. 2018, 113, 94-104. [CrossRef]

38. Li, K.; Chi, G.; Wang, L.; Xie, Y.; Wang, X.; Fan, Z. Identifying the critical riparian buffer zone with the strongest linkage between landscape characteristics and surface water quality. Ecol. Indic. 2018, 93, 741-752. [CrossRef]

39. Irwin, E.G.; Bockstael, N.E. The evolution of urban sprawl: Evidence of spatial heterogeneity and increasing land fragmentation. Proc. Natl. Acad. Sci. USA 2007, 104, 20672-20677. [CrossRef]

40. Sokolow, A.D. Governmental Response to Urbanization. Three Townships on the Rural-Urban Gradient; Agricultural Economic Reports; USDA: Washington, DC, USA, 1968; Volume 132.

41. Whittaker, R. Communities and Ecosystems, 2nd ed.; MacMillan: New York, NY, USA, 1975.

42. Mcdonnell, M.J.; Pickett, S.T.A. Ecosystem structure and function along urban-rural gradients: An unexploited opportunity for ecology. Ecology 1990, 71, 1232-1237. [CrossRef]

43. Himes, A.; Puettmann, K.; Muraca, B. Trade-offs between ecosystem services along gradients of tree species diversity and values. Ecosyst. Serv. 2020, 44, 101133. [CrossRef]

44. Diaz-Palacios-Sisternes, S.; Ayuga, F.; Garcia, A.I. A method for detecting and describing land use transformations: An examination of Madrid's southern urban-rural gradient between 1990 and 2006. Cities 2014, 40, 99-110. [CrossRef]

45. Klausnitzer, B.; Richter, K. Presence of an urban gradient demonstrated for carabid associations. Oecologia 1983, 59, 79-82. [CrossRef] [PubMed]

46. Zhao, P.; Wan, J. Land use and travel burden of residents in urban fringe and rural areas: An evaluation of urban-rural integration initiatives in Beijing. Land Use Policy 2021, 103, 105309. [CrossRef]

47. Kong, F.; Nakagoshi, N. Spatial-temporal gradient analysis of urban green spaces in Jinan, China. Landsc. Urban Plan. 2006, 78, 147-164. [CrossRef]

48. Yeh, C.; Huang, S.L. Investigating spatiotemporal patterns of landscape diversity in response to urbanization. Landsc. Urban Plan. 2009, 93, 151-162. [CrossRef]

49. Li, Q.; Li, T.; Yang, M.Z.; Ying, W. Spatiotemporal variation of ecosystem services value based on gradient analysis in Wuhan: 2000-2010. Acta Ecol. Sin. 2017, 37, 2118-2125.

50. Foresman, T.W.; Pickett, S.T.A.; Zipperer, W.C. Methods for spatial and temporal land use and land cover assessment for urban ecosystems and application in the greater Baltimore-Chesapeake region. Urban Ecosyst. 1997, 1, 201-216. [CrossRef]

51. Hou, L.; Wu, F.; Xie, X. The spatial characteristics and relationships between landscape pattern and ecosystem service value along an urban-rural gradient in Xi'an city, China. Ecol. Indic. 2020, 108, 105720. [CrossRef]

52. Li, X.W.; Zhang, L.N.; Liang, C. A GIS-based buffer gradient analysis on spatiotemporal dynamics of urban expansion in Shanghai and its major satellite cities. Procedia Environ. Sci. 2010, 2, 1139-1156. [CrossRef]

53. Cao, Y.G.; Bai, Z.K.; Zhou, W.; Ai, G. Gradient analysis of urban construction land expansion in the Chongqing urban area of China. Urban Plann. Dev. 2015, 141, 05014009. [CrossRef]

54. Radford, K.G.; James, P. Changes in the value of ecosystem services along a rural-urban gradient: A case study of Greater Manchester, UK. Landsc. Urban Plan. 2013, 109, 117-127. [CrossRef]

55. Seifu, W.; Elias, E.; Gebresamuel, G.; Khanal, S. Impact of land use type and altitudinal gradient on topsoil organic carbon and nitrogen stocks in the semi-arid watershed of northern Ethiopia. Heliyon 2021, 7, e6770. [CrossRef]

56. Zhou, T.; Koomen, E.; van Leeuwen, E.S. Residents' preferences for cultural services of the landscape along the urban-rural gradient. Urban For. Urban Gree. 2018, 29, 131-141. [CrossRef]

57. Hutyra, L.R.; Yoon, B.; Alberti, M. Terrestrial carbon stocks across a gradient of urbanization: A study of the Seattle, WA region. Glob. Chang. Biol. 2011, 17, 783-797. [CrossRef] 
58. Larondelle, N.; Haase, D. Urban ecosystem services assessment along a rural-urban gradient: A cross-analysis of European cities. Ecol. Indic. 2013, 29, 179-190. [CrossRef]

59. Jaeger, J.A.G. Landscape division, splitting index, and effective mesh size: New measures of landscape fragmentation. Landsc. Ecol. 2000, 15, 115-130. [CrossRef]

60. Weng, Y. Spatiotemporal changes of landscape pattern in response to urbanization. Landsc. Urban Plan. 2007, 81, 341-353. [CrossRef]

61. Millennium Ecosystem Assessment. Ecosystems and Human Well-Being; Island Press: Washington, DC, USA, 2005.

62. Chen, W.X.; Zeng, J.; Zhong, M.X.; Pan, S.P. Coupling analysis of ecosystem services value and economic development in the Yangtze River Economic Belt: A case study in Hunan Province, China. Remote Sens. 2021, 13, 1552. [CrossRef]

63. Mugiraneza, T.; Ban, Y.F.; Haas, J. Urban land cover dynamics and their impact on ecosystem services in Kigali, Rwanda using multi-temporal Landsat data. Remote Sens. Appl. Soc. Environ. 2018, 13, 234-246. [CrossRef]

64. Wang, B.; Liu, Z.; Mei, Y.; Li, W. Assessment of ecosystem service quality and its correlation with landscape patterns in Haidian District, Beijing. Int. J. Environ. Res. Public Health 2019, 16, 1248. [CrossRef] [PubMed]

65. Zang, Z.; Zou, X.; Zuo, P.; Song, Q.; Wang, C.; Wang, J. Impact of landscape patterns on ecological vulnerability and ecosystem service values: An empirical analysis of Yancheng Nature Reserve in China. Ecol. Indic. 2017, 72, 142-152. [CrossRef]

66. Chen, W.X.; Chi, G.Q.; Li, J.F. The spatial aspect of ecosystem services balance and its determinants. Land Use Policy 2020, 90, 104263. [CrossRef]

67. Dai, X.; Wang, L.; Tao, M.; Huang, C.; Sun, J.; Wang, S. Assessing the ecological balance between supply and demand of blue-green infrastructure. J. Environ. Manag. 2021, 288, 112454. [CrossRef]

68. Serraino, M.; Lucchi, E. Energy efficiency, heritage conservation, and landscape integration: The case study of the San Martino Castle in Parella (Turin, Italy). Energy Procedia 2017, 133, 424-434. [CrossRef]

69. Cabral, A.I.R.; Costa, F.L. Land cover changes and landscape pattern dynamics in Senegal and Guinea Bissau borderland. Appl. Geogr. 2017, 82, 115-128. [CrossRef]

70. Zhang, Y.; Liu, Y.; Zhang, Y.; Liu, Y.; Zhang, G.; Chen, Y. On the spatial relationship between ecosystem services and urbanization: A case study in Wuhan, China. Sci. Total Environ 2018, 637-638, 780-790. [CrossRef] [PubMed]

71. Su, S.; Xiao, R.; Jiang, Z.; Zhang, Y. Characterizing landscape pattern and ecosystem service value changes for urbanization impacts at an eco-regional scale. Appl. Geogr. 2012, 34, 295-305. [CrossRef]

72. Batar, A.; Watanabe, T.; Kumar, A. Assessment of land-use/land-cover change and forest fragmentation in the Garhwal Himalayan region of India. Environments 2017, 4, 34. [CrossRef]

73. Wei, L.; Luo, Y.; Wang, M.; Su, S.L.; Pi, J.H.; Li, G. Essential fragmentation metrics for agricultural policies: Linking landscape pattern, ecosystem service and land use management in urbanizing China. Agric. Syst. 2020, 182, 102833. [CrossRef]

74. Liu, J.; Liu, M.; Zhuang, D.; Zhang, Z.; Deng, X. Study on spatial pattern of land-use change in China during 1995-2000. Sci. China Ser. D 2003, 46, 373-384.

75. Liu, J.; Zhang, Z.; Xu, X.; Kuang, W.; Zhou, W.; Zhang, S.; Li, R.; Yan, C.; Yu, D.; Wu, S.; et al. Spatial patterns and driving forces of land use change in China during the early 21st century. J. Geogr. Sci. 2010, 20, 483-494. [CrossRef]

76. Ning, J.; Liu, J.; Kuang, W.; Xu, X.; Zhang, S.; Yan, C.; Li, R.; Wu, S.; Hu, Y.; Du, G.; et al. Spatiotemporal patterns and characteristics of land-use change in China during 2010-2015. J. Geogr. Sci. 2018, 28, 547-562. [CrossRef]

77. Song, W.; Deng, X. Land-use/land-cover change and ecosystem service provision in China. Sci. Total Environ. 2017, 576, 705-719. [CrossRef] [PubMed]

78. Wuhan Institute of Urban Planning and Design. Ecoframework Planning of Wuhan Urban Development Area; Wuhan Institute of Urban Planning and Design: Wuhan, China, 2011.

79. Turner, M.G. Landscape ecology: The effect of pattern on process. Annu. Rev. Ecol. Syst. 1989, 20, 171-197. [CrossRef]

80. McGarigal, K.; Cushman, S.A.; Ene, E.; FRAGSTATS: Spatial Pattern Analysis Program for Categorical and Continuous Maps. Computer Software Program Produced by the Authors at the University of Massachusetts, Amherst. 2012. Available online: http:/ / www.umass.edu/landeco/research/fragstats/fragstats.html (accessed on 2 December 2020).

81. Fisher, B.; Turner, R.K.; Morling, P. Defining and classifying ecosystem services for decision making. Ecol. Econ. 2009, 68, 643-653. [CrossRef]

82. Costanza, R.; Darge, R.C.; de Groot, R.; Farber, S.; Grasso, M.; Hannon, B.; Limburg, K.E.; Naeem, S.; Oneill, R.V.; Paruelo, J.M. The value of the world's ecosystem services and natural capital. Nature 1997, 387, 253-260. [CrossRef]

83. Xie, G.D.; Zhen, L.; Lu, C.X.; Xiao, Y.; Chen, C. Expert knowledge based valuation method of ecosystem services in China. J. Nat. Res. 2008, 23, 911-919.

84. Costanza, R.; de Groot, R.; Sutton, P.; van der Ploeg, S.; Anderson, S.J.; Kubiszewski, I.; Farber, S.; Turner, R.K. Changes in the global value of ecosystem services. Glob. Environ. Chang. 2014, 26, 152-158. [CrossRef]

85. Ye, Y.; Bryan, B.A.; Zhang, J.; Connor, J.D.; Chen, L.; Qin, Z.; He, M. Changes in land-use and ecosystem services in the Guangzhou-Foshan Metropolitan Area, China from 1990 to 2010: Implications for sustainability under rapid urbanization. Ecol. Indic. 2018, 93, 930-941. [CrossRef]

86. Yi, H.; Güneralp, B.; Filippi, A.M.; Kreuter, U.P.; Güneralp, İ. Impacts of land change on ecosystem services in the San Antonio River Basin, Texas, from 1984 to 2010. Ecol. Econ. 2017, 135, 125-135. [CrossRef] 
87. Chen, K.Q.; Long, H.L.; Liao, L.W.; Tu, S.S.; Li, T.T. Land use transitions and urban-rural integrated development: Theoretical framework and China's evidence. Land Use Policy 2020, 92, 104465. [CrossRef]

88. Ibrahim, J.G.; Zhu, H.; Garcia, R.I.; Guo, R. Fixed and random effects selection in mixed effects models. Biometrics 2011, 67, 495-503. [CrossRef]

89. Mundlak, Y. On the pooling of time series and cross section data. Econometrtca 1978, 46, 69-85. [CrossRef]

90. Lv, J.J.; Ma, T.; Dong, Z.W.; Yao, Y.; Yuan, Z.H. Temporal and spatial analyses of the landscape pattern of Wuhan city based on remote sensing images. Int. J. Geo-Inf. 2018, 7, 340. [CrossRef]

91. Wang, Y.; Li, X.; Zhang, Q.; Li, J.F.; Zhou, X.W. Projections of future land use changes: Multiple scenarios-based impacts analysis on ecosystem services for Wuhan city, China. Ecol. Indic. 2018, 94, 430-445. [CrossRef]

92. Zheng, W.; Ke, X.; Zhou, T.; Yang, B. Trade-offs between cropland quality and ecosystem services of marginal compensated cropland-A case study in Wuhan, China. Ecol. Indic. 2019, 105, 613-620. [CrossRef]

93. Wang, B.; Gao, P.; Niu, X.; Sun, J. Policy-driven China's Grain to Green Program: Implications for ecosystem services. Ecosyst. Serv. 2017, 27, 38-47. [CrossRef]

94. Zhang, Z.; Zhao, W.; Gu, X. Changes resulting from a land consolidation project (LCP) and its resource-environment effects: A case study in Tianmen City of Hubei Province, China. Land Use Policy 2014, 40, 74-82. [CrossRef]

95. Jiang, G.; Zhang, R.; Ma, W.; Zhou, D.; Wang, X.; He, X. Cultivated land productivity potential improvement in land consolidation schemes in Shenyang, China: Assessment and policy implications. Land Use Policy 2017, 68, 80-88. [CrossRef]

96. He, S.W.; Yu, S.; Li, G.D.; Zhang, J.F. Exploring the influence of urban form on land-use efficiency from a spatiotemporal heterogeneity perspective: Evidence from 336 Chinese cities. Land Use Policy 2020, 95, 104576. [CrossRef]

97. Levin, S.A. The problem of pattern and scale in ecology. Ecology 1992, 73, 1943-1967. [CrossRef]

98. National Bureau of Statistics PRC. Wuhan Statistical Yearbook; China Statistics Press: Beijing, China, 2020.

99. Wickham, J.; Riitters, K.H. Influence of high-resolution data on the assessment of forest fragmentation. Landsc. Ecol. 2019, 34, 2169-2182. [CrossRef] [PubMed] 